\title{
Weak, Seismogenic Faults Inherited From Mesozoic Rifts Control Mountain Building in the Andean Foreland
}

\author{
Sam Wimpenny ${ }^{1 *}$ \\ ${ }^{1}$ COMET, Bullard Laboratories, Department of Earth Sciences, \\ University of Cambridge, UK \\ *email:sew57@cam.ac.uk
}

1 Key Points:

This paper is a pre-print, therefore has not been through peer review and is currently being considered for publication in Geophysics, Geochemistry, Geosystems.

- New earthquake data show the Andean forelands are breaking up in compression to $30-45 \mathrm{~km}$ depth in areas that experienced Mesozoic rifting.

- Force-balance calculations demonstrate that the effective coefficients of static friction on faults inherited from the rifts is $<0.2$.

- These frictionally-weak, seismogenic faults control the style of active mountain building in the forelands.

Key Words:

- 7230 Seismicity and Tectonics

- 8102 Continental orogenic belts and inversion tectonics

- 8163 Rheology and friction of fault zones

- 8004 Dynamics and mechanics of faulting

- 8045 Role of fluids 


\section{Abstract}

New earthquake focal mechanism and centroid depth estimates show that the deformation style in the forelands of the Andes is spatially correlated with rift systems that stretched the South American lithosphere in the Mesozoic. Where the rifts trend sub-parallel to the Andean range front, normal faults inherited from the rifts are being reactivated as reverse faults, causing the $30-45 \mathrm{~km}$ thick seismogenic layer to break up. Where the rift systems are absent from beneath the range front, the seismogenic layer is bending and being thrust beneath the Andes like a rigid plate. Force-balance calculations show that the faults inerhited from former rift zones have an effective coefficient of static friction $\mu^{\prime}<0.2$. In order for these frictionally-weak faults to remain seismogenic in the lower crust, their wall rocks are likely to be formed of dry granulite. Xenolith data support this view, and suggest that parts of the lower crust are now mostly metastable, having experienced temperatures at least $75-250{ }^{\circ} \mathrm{C}$ hotter than present. The conditions in the lower crust make it unlikely that highly-pressurised free water, or networks of intrinsically-weak phyllosilicate minerals, are the cause of their low effective friction, as, at such high temperatures, both mechanisms would cause the faults to deform through viscous creep and not frictional slip. Therefore pre-existing faults in the Andean forelands have remained weak and seismogenic after reactivation, and have influenced the style of mountain building in South America. However, the controls on their mechanical properties in the lower crust remain unclear.

\section{Plain Language Summary}

This study is concerned with the controls on how mountain ranges grow. I show that the locations and types of earthquakes along the margins of the Andes mountains, which are generated when the mountain range grows, vary systematically with the positions of ancient fault zones. Where ancient faults lie along the margins of the Andes the entire crust is breaking up through slip on these faults. Where the same faults are not present along the margins of the Andes, the crust is being pushed beneath the mountains like a rigid plate. Therefore, the strength of faults along the margins of the Andes play a critical role in the growth of the mountain range. Notably, the earthquake-generating faults along the margins of the Andes are much weaker than predicted by laboratory experiments, and the physical reason for their weakness remains unclear. 


\section{Introduction}

The frictional properties of faults in the forelands of mountain ranges may play a key role in controlling the style and location of mountain building [Jackson, 2002a; Butler et al., 2006]. Where faults are too strong to rupture in response to the forces acting through the lithosphere, the foreland may behave as a rigid plate and be thrust beneath the mountain range below a shallowly-dipping décollement. In contrast, where faults are weak enough to rupture in response to the forces acting through the lithosphere, the foreland may break up, creating a region of distributed deformation and intense seismicity.

These contrasting styles of mountain building have been recognised along the eastern margin of the Andes in South America on the basis of outcrop patterns and fault spacing [e.g. Jordan et al., 1983; Kley et al., 1999; Ramos, 2010b], and the focal mechanisms and depth extent of seismicity [e.g. Suarez et al., 1983; Devlin et al., 2012]. The along-strike changes in the foreland deformation style correlate with proxies for the integrated strength of the lithosphere such as the effective elastic thickness [Watts et al., 1995; Stewart and Watts, 1997], as well as the pattern and timing of Miocene uplift [Gubbels et al., 1993; Kennan et al., 1997] and rotations inferred from paleomagnetic declination anomalies [Lamb, 2000; Barke et al., 2007] within the adjacent high Andes. Therefore, the Andean forelands are a unique environment to study the frictional properties of faults and their influence on the growth of mountain ranges.

Our understanding of fault friction remains rooted in the results of laboratory experiments. Lab measurements of the static coefficient of friction $(\mu)$ for most rock types are consistently between 0.6 and 0.85, a widely-applied result known as 'Byerlee's Law' [Byerlee, 1978]. However, in-situ estimates of the effective coefficient of static friction $\left(\mu^{\prime}\right)$ on seismogenic faults are between 0.05 and 0.3 [Copley, 2018]. The differences between the laboratory and in-situ estimates of static friction have been accounted for by invoking either: (1) highly-pressurised pore fluids, often assumed to be water, that reduce the effective stresses within the cores of active faults [Hubbert and Rubey, 1959], or (2) networks of intrinsically-weak phyllosilicates produced through water-mediated alteration of the rocks in the cores of active faults [Imber et al., 1997]. Geological evidence of both transiently-high fluid pressures and phyllosilicate-rich lithologies is widespread within ancient continental fault zones exhumed from depths of less than $20 \mathrm{~km}$, indicating that water-assisted processes may be critical to generating frictionally-weak faults in the upper crust [e.g. Sibson, 1990; Collettini et al., 2019].

Despite the consensus regarding the geological controls on fault mechanics in the upper crust, the 
mechanics of seismogenic faults in the lower crust remain enigmatic. For example, along the margins of the Andes mountains in central Peru, seismogenic faults cutting through the $\sim 40 \mathrm{~km}$ thick foreland crust have been shown to have a low effective coefficient of friction compared to Byerlee's Law [Wimpenny et al., 2018]. Unlike most continental fault zones, which only generate earthquakes in the upper 10-20 km of the crust, these faults in central Peru remain seismogenic into the lower crust. For faults to remain seismogenic at such high pressures and temperatures, the lower crust that surrounds them is thought to be formed of a load-bearing network of anhydrous minerals that contains little or no free pore water [Yardley and Valley, 1997; Jackson et al., 2004]. As a result, there is reason to question whether the same water-assisted mechanisms that have been invoked to account for weak faults in the upper crust are also applicable to these seismogenic, lower-crustal fault zones. Vast areas of anhydrous rocks regularly form the forelands of the highest mountain ranges on Earth [Jackson et al., 2021; Weller et al., 2021]. Therefore, developing an understanding of the mechanics of fault zones within the anhydrous lower crust, like those in central Peru, is important for understanding the style of deformation along the margins of active and ancient mountain ranges.

In this study, I determine the mechanical properties and Mesozoic-Cenozoic history of the active fault zones along the eastern margins of the Andes, and explore how these faults influence the distribution and style of mountain building. I begin by using new estimates of the focal mechanisms and centroid depths of earthquakes to map out variations in the style of crustal deformation throughout the Andean forelands. I then compare the pattern of seismicity with the location of pre-existing faults in the South American foreland lithosphere. I place bounds on the frictional properties of the seismogenic faults within the Andean forelands using force-balance calculations, and use published xenolith thermobarometry and thermo-kinematic modelling to constrain the geological conditions in the lower crust through which the seismogenic faults cut. Finally, I discuss the implications of these findings for structural inheritance and growth of mountain ranges, and the mechanisms that may account for the frictional properties of faults within the anhydrous lower crust.

\section{Seismicity in the Forelands of the Andes}

To determine the focal mechanisms and centroid depths of moderate-magnitude earthquakes in the Andean forelands, I used waveform modelling of teleseismic $P$ and $S H$ waves and their depth phases $(p P, s P$ and $s S)$. For earthquakes of $M_{w} \gtrsim 5.4$, I fit the shape and amplitude of the long-period (15-100 s) teleseismic $P$ and $S H$ waves using the body-waveform inversion algorithm of Zwick et al. 
[1994]. This method has been used extensively in the region [e.g. Devlin et al., 2012] and yields earthquake centroid depth estimates with uncertainties of $\pm 2-5 \mathrm{~km}$. For earthquakes of $4.8<M_{w}<$ 5.4 typically only the $P$ waves, and the $p P$ and $s P$ depth phases, are clear on teleseismic seismograms. I calculated the depths of these smaller-magnitude earthquakes by fitting synthetic waveforms to either broadband vertical-component seismograms, or to a stack of short-period vertical-component seismograms recorded at small-aperture seismic arrays [e.g. Craig et al., 2012]. This method can typically constrain the centroid depth to within $\pm 1-3 \mathrm{~km}$. All of these methods have been described extensively in the literature [e.g. Molnar and Lyon-Caen, 1989; Taymaz et al., 1990; Craig et al., 2011], therefore further details regarding the data processing, inversion strategy, the velocity structure used and the modelling uncertainties are provided in Supplementary Text S1.

In addition to my own modelling of 45 new earthquakes (see Supplementary Table 1 and Supplementary Figures 4-50), I compiled 108 earthquake focal mechanisms and centroid depths derived using similar methods from the literature [Suarez et al., 1983; Chinn and Isacks, 1983; Kadinsky-Cade et al., 1985; Assumpção and Suarez, 1988; Assumpção and Araujo, 1993; Alvarado et al., 2005; Alvarado and Beck, 2006; Meigs and Nabelek, 2010; Devlin et al., 2012; Wimpenny et al., 2018]. Microseismicity located using local seismometer networks provide additional constraints on the depth extent of seismicity within the forelands [Smalley and Isacks, 1990; Smalley et al., 1993; Cahill et al., 1992; Dorbath et al., 1986; Legrand et al., 2005; Dimate et al., 2003; Richardson et al., 2012; Vaca et al., 2019; Rivas et al., 2019]. The resulting compilation of earthquakes is shown in Figure 1 along with the distribution of the Moho depth in the forelands, which varies between $35 \mathrm{~km}$ and $48 \mathrm{~km}$ [Assumpção et al., 2013; Poveda et al., 2015; Condori et al., 2017]. I describe the along-strike variation in the earthquake focal mechanisms and centroid depths below.

Throughout the northern Andes of Venezuela, Colombia and Ecuador, $\sim$ N-S to $\sim$ NE-SW striking reverse and strike-slip faulting is mostly concentrated along the range front and extends from 5-49 $\mathrm{km}$ depth. Aftershocks recorded by temporary seismometer deployments in Colombia [Dimate et al., 2003] and Ecuador [Legrand et al., 2005] following $M_{w} 6$ earthquakes located microseismicity down to $30 \mathrm{~km}$. Seismicity deeper than $30 \mathrm{~km}$ is only found in a cluster of four earthquakes with centroid depths between $34 \mathrm{~km}$ and $49 \mathrm{~km}$ depth that ruptured faults within the Garzon Massif of south-central Colombia (Figure 1b,c). These four earthquakes do not appear to be representative of the depth extent of seismicity along the whole northern Andes, as elsewhere both moderate-magnitude earthquakes and microseismicity are consistently confined to depths of less than $30 \mathrm{~km}$.

Earthquakes east of the range front in Colombia have shallow $(<20 \mathrm{~km})$ normal-faulting mechanisms, 
indicating that the top of the foreland crust is in extension. These normal-faulting earthquakes have previously been interpreted to reflect the bending of the foreland lithosphere under the weight of the Andes [Wimpenny et al., 2018]. At a similar distance east of the range front of the Ecuadorian Andes, the shallow crust at $15 \mathrm{~km}$ depth is in compression. Therefore the stress state within the top $20 \mathrm{~km}$ of the foreland crust varies perpendicular to the strike of the mountain range, as well as along strike.

In northern and central Peru, the forelands are characterised by reverse-faulting earthquakes that extend throughout the crust from 5-42 km depth. The same depth distribution of earthquakes has also been observed by a temporary seismometer deployment that recorded microseismicity down to 45 km depth beneath the forelands of central Peru [Dorbath et al., 1986; Suárez et al., 1990]. Although the majority of the earthquakes are concentrated beneath the steep topography along the eastern margin of the Andes, a significant number lie well into the foreland forming a $\sim 300 \mathrm{~km}$-wide zone of distributed compressional deformation. This zone of distributed deformation coincides with crystalline basement highs that have been uplifted relative to the foreland basin sediments during the Neogene (e.g. the Contoya Arch; see Kley et al. [1999]).

There have been few earthquakes in the sub-Andean fold-thrust belt that wraps around the margins of the central Andean plateau in southern Peru and Bolivia. The largest earthquakes accommodate lowangle thrust faulting at depths $\leq 20 \mathrm{~km}$, whilst the lower 10-20 km of the foreland crust has experienced only one moderate-magnitude earthquake in the last 50 years - a reverse-faulting earthquake at 31 $\mathrm{km}$ depth. A $7 \mathrm{~km}$ deep, normal-faulting earthquake east of the range front in southern Peru indicates that the shallow part of the foreland crust is in extension. Geodetic, seismological and structural observations suggest that the foreland crystalline basement is underthrusting the central Andean plateau along a shallowly-dipping décollement in this region [Lyon-Caen et al., 1985; Allmendinger and Gubbels, 1996; Brooks et al., 2011; Weiss et al., 2015].

A sharp transition in the foreland seismicity occurs across the Bolivia-Argentina border. At latitude $23^{\circ} \mathrm{S}$, the foreland transitions from being predominantly aseismic within the Bolivian sub-Andes to the north, to experiencing frequent $\sim \mathrm{N}-\mathrm{S}$ striking reverse- and low-angle thrust-faulting earthquakes in the Santa Barbara Ranges to the south. Across the same section of foreland, the trains of closely-spaced anticlines that characterise the surface morphology in the Bolivian sub-Andes abruptly stop, and the foreland structures transition southwards into widely-spaced, east and west-verging reverse faults in the Santa Barbara Ranges [Kley and Monaldi, 2002]. Microseismicity and moderate-magnitude earthquakes beneath Santa Barbara have been recorded down to $35 \mathrm{~km}$ depth [Cahill et al., 1992]. 
South of latitude $26^{\circ} \mathrm{S}$, the seismicity becomes more spatially distributed over an area that stretches 300-400 km from the margins of the Andes into the foreland, coincident with the basement uplifts of the Sierra Pampeanas [Jordan et al., 1983]. The focal mechanisms indicate that the earthquakes are predominantly on $\sim \mathrm{N}-\mathrm{S}$ striking reverse-faults, with a component of strike-slip faulting on $\sim \mathrm{N}-\mathrm{S}$ or $\sim \mathrm{E}-\mathrm{W}$ striking planes. Most of the moderate-magnitude seismicity and microseismicity is concentrated between $10 \mathrm{~km}$ and $30 \mathrm{~km}$ depth, but seismicity does extend to a maximum of $40 \mathrm{~km}$ depth beneath the forelands [Smalley and Isacks, 1990; Smalley et al., 1993].

The along-strike variability in the depth distribution of seismicity within the Andean forelands is consistently mirrored by the microseismicity recorded by local seismometer networks, indicating that the variations are real and are not related to limited sampling of infrequent moderate-magnitude earthquakes (Figure 2). The centroid depth distributions show a single peak within the mid-crust [Chinn and Isacks, 1983], and all of the seismicity is contained within a single layer that is similar in thickness to the crust (Figure 2). These observations are consistent with faults supporting the forces acting through the foreland lithosphere via resistance to slip in a seismogenic layer, which varies from $30 \mathrm{~km}$ thick in the northern Andes to 40-45 km thick in the central Peru and the south-central Andes. The seismogenic layer is underlain by a mostly aseismic mantle lithosphere [e.g. Maggi et al., 2000b]. In addition to the along-strike variability in the thickness of the seismogenic layer within the forelands (Figure 1c), there is clear map-view variability in the frequency and spatial distribution of moderate-magnitude earthquakes. I explore the controls on these patterns further in the next section.

\section{Relationship Between Seismicity and Foreland Structure}

\subsection{Flat Slabs}

The structure of the subducting Nazca Plate has been inferred to correlate with the pattern of seismicity within the Andean forelands. Jordan et al. [1983] showed that, where the Nazca Plate subducts sub-horizontally beneath the Andes in northern Argentina (see regions marked 'flat slab' on Figure 1b), the adjacent forelands are characterised by frequent compressional earthquakes that extend throughout the crust. In contrast, where the Nazca Plate dips steeply, such as around the central Andean plateau, the forelands experience less frequent seismicity that is mostly confined to the upper crust [see also Gutscher et al., 2000]. The physical explanation for these trends was that the flat slab can cool the overriding lithosphere and increase the horizontal force transmitted between the subducting 
and overriding plates, causing the whole foreland crust in areas of flat-slab subduction to break up in compressional earthquakes.

The general patterns within the south-central Andes described by Jordan et al. [1983] and Gutscher et al. [2000] are also seen in the updated earthquake catalogue presented in Figure 1. Foreland seismicity above the flat slab in Argentina appears deeper and more frequent than in the region to the north in the Bolivia sub-Andes. However, the same patterns are less clear in the northern Andes. Within northern Ecuador and Colombia, where newer models of the Nazca Plate geometry show it dipping continuously into the mantle [Hayes et al., 2018], the forelands are also characterised by frequent compressional earthquakes throughout the entire crust to depths of $30-49 \mathrm{~km}$, just as in the areas with a flat slab (Figure 1). The moment release from foreland seismicity is larger in Ecuador than any other part of the Andean forelands, demonstrating that the amount of seismogenic deformation in the forelands does not always peak in areas underlain by a flat slab (Table 1). In addition, the deepest earthquakes anywhere in the Andean foreland occur in southern Colombia (Figure 1) - a region with a steeply dipping slab. Therefore, when considering the pattern of seismicity along the whole Andean chain, it appears that the shape of the Nazca Plate is not necessarily the controlling factor on the depth extent, moment release or mechanisms of the foreland earthquakes.

\section{$3.2 \quad$ Inherited Structure}

The influence of pre-Andean deformation structures, particularly those associated with Mesozoic rifting, on the location and style of active deformation is seen throughout the Andean forelands [e.g. Coira et al., 1982; Kley et al., 2005; Mora et al., 2006; Charrier et al., 2015]. These continental rifts were active between the late Permian and the Cretaceous, developed in response to the break up of Pangea [Ramos, 2010b; Spikings et al., 2016] and often follow boundaries inherited from earlier episodes of deformation [e.g. Ramos et al., 2002]. Figure 3 shows the locations of the major Mesozoic rift-related faults mapped by Ramos [2009] and McGroder et al. [2015] based on seismic reflection data and geological outcrop, and their relationship with the foreland seismicity and the structural style of deformation.

Within northern and central Peru, and in the Sierra Pampeanas of Argentina, the Mesozoic rift systems form $\sim 300 \mathrm{~km}$ wide belts of range-parallel faults that extend from the eastern margin of the high Andes into the foreland. In these regions, the forelands are associated with distributed upper- and lower-crustal compressional earthquakes that closely follows the map-view shape of the rift systems. 
At the surface the deformation is mostly characterised by 'thick-skinned' structures, with crystalline basement being exhumed towards the surface along steeply-dipping reverse faults [Kley et al., 1999; Ramos et al., 2002]. In the Marañon Basin of northern Peru the rift systems trend beneath a superficial 'thin-skinned' fold-thrust belt characterised by trains of anticlines formed of sediments [Mathalone and Montoya, 1995; Hermoza et al., 2005], whilst the lower crust beneath the fold-thrust belt still remains highly seismogenic [Suarez et al., 1983].

In the northern Andes of Ecuador, Colombia and Venezuela, the Mesozoic rift systems trend through the mountain range and parallel to the eastern range front of the Andes, but do not extend more than $\sim 50 \mathrm{~km}$ into the forelands. The distribution of seismicity mirrors this pattern, with reverse and strike-slip faulting earthquakes mostly clustering beneath the range front. In some cases, recent earthquakes beneath the range front can even be directly linked to inverted normal fault structures mapped at the surface or in seismic reflection profiles [e.g. Legrand et al., 2005; Mora et al., 2006].

Beneath the Santa Barbara Ranges of northern Argentina, the western branch of the Salta Rift consists of basins bound by $\sim \mathrm{N}-\mathrm{S}$ striking normal faults that trend beneath the Andean range front. The same region has experienced a number of moderate-magnitude earthquakes on $\sim \mathrm{N}$-S striking reverse faults and shows evidence for normal-fault reactivation in outcrop [Kley et al., 2005]. However, in the eastern branch of the Salta Rift, where the rift-related faults strike $\sim \mathrm{E}-\mathrm{W}$ and are almost perpendicular to the range front, there have been no recent moderate-magnitude earthquakes. Therefore, the Mesozoic rifts appear to only be associated with moderate-magnitude earthquakes if the inherited normal faults and rift fabrics strike sub-parallel to the range front.

In contrast to the northern and south-central Andes, within southern Peru and Bolivia the Mesozoic rift systems trend through the interior of the central Andean plateau [e.g. Sempere et al., 2002], and rifted basement is mostly absent beneath the range front (Figure 3a). Around the margins of the plateau, the thin-skinned sub-Andean fold-thrust belt has experienced far fewer earthquakes than the northern and southern Andean forelands, and the largest earthquakes are shallow, low-angle thrust faulting events. East of the range front, there have only been two earthquakes; the shallowest being a normal-faulting earthquake with a centroid depth of $7 \mathrm{~km}$, and the deepest being a reverse-faulting earthquake with a centroid depth of $31 \mathrm{~km}$. The same pattern of seismicity has been recognised in the Indian forelands south of Tibet [e.g. Molnar et al., 1977], and is interpreted to reflect bending of the lithosphere in response to the vertical load of the mountain belt.

The remarkable spatial correlation between regions of frequent lower-crustal earthquakes, the Mesozoic 
rift systems, and the deformation style within the forelands suggests a physical link. The simplest explanation is that, along the margins of the northern and south-central Andes, range-parallel normal faults inherited from the Mesozoic rifts are being reactivated within the mid-lower crust as reverse faults, causing the whole seismogenic layer to break up in compression. A summation of the earthquake moment tensors in these regions using the method of Kostrov [1974] suggests that 40-100\% of the range-perpendicular shortening rates measured from GPS can be accounted for by seismogenic slip on faults (Table 1). In contrast, around the central Andean plateau the range-perpendicular shortening rates from recent seismicity are $0.5-25 \%$ of the rates inferred from GPS (Table 1). Beneath the sub-Andes, the foreland is presumably too strong to deform significantly in response to the forces associated with mountain building. Therefore, instead of the foreland seismogenic layer breaking up in compression, it is bending and being thrust beneath the central Andean plateau as a relatively rigid plate [Watts et al., 1995]. Shortening is instead accommodated by slip on a décollement that separates the rigid foreland from the overlying sub-Andean fold-thrust belt and by viscous shortening of the lower crust beneath the central Andean plateau [Allmendinger and Gubbels, 1996; Lamb, 2000; Brooks et al., 2011].

\section{Strength of Inherited Faults in the Forelands}

The pattern of seismicity in the forelands of the northern and south-central Andes demonstrates that faults inherited from Mesozoic rifts are breaking in reverse-faulting earthquakes, implying that the forces acting on these structures exceeds their frictional resistance to slip. In this section, I estimate the forces acting on these faults and place bounds on their frictional properties.

Gravity acting on differences in the thickness and density of the crust and mantle lithosphere between the Andes and its forelands generates a horizontal buoyancy force $F_{b}$ that must be balanced by a horizontal force acting through the foreland lithosphere $F_{f}$, and resistance to deformation within the mountains [Dalmayrac and Molnar, 1981; Molnar and Lyon-Caen, 1988]. It is likely that many parts of the Andes are close to the state of $F_{b} \approx F_{f}$, as the highest portions of the mountain range have relatively flat, plateau-like topography [Lamb, 2006]. In addition, in the most rapidly-deforming areas of the high Andes, such as the Cordillera Blanca in central Peru and in the Altiplano of southern Peru, seismicity rates and fault slip rates imply that deviations from $F_{b}=F_{f}$ are $\lesssim 0.5-0.7 \times 10^{12} \mathrm{~N}$ per metre along-strike, which is $\lesssim 10-25 \%$ of $F_{b}$ [Wimpenny et al., 2020]. Therefore, to place a bound on the forces acting through the forelands $F_{f}$, I calculated the buoyancy forces $F_{b}$ in eight different 
regions of the Andes using the method described in Copley and Woodcock [2016], with the range of parameters given in Table 2. The eight different regions were selected to encompass sections of the Andes where deformation within the mountains and forelands, and the height of the mountains, are relatively continuous along-strike.

Within Ecuador, Colombia and northern Peru, where the Andes are $2.8-3.5 \mathrm{~km}$ high, the calculated buoyancy forces are $3-4 \times 10^{12} \mathrm{~N} / \mathrm{m}$ (Figure 4a). In Ecuador there is evidence for shortening within the high Andes [Alvarado et al., 2014], suggesting the buoyancy forces slightly under-estimate the horizontal force acting through the foreland lithosphere in this region. In central Peru, southern Peru, Bolivia, the Puna and high mountains of northern Argentina, where the Andes are $3.8-4.5 \mathrm{~km}$ high, the calculated buoyancy forces are $5-6.5 \times 10^{12} \mathrm{~N} / \mathrm{m}$ (Figure 4a). In these areas where the buoyancy forces are largest, the high Andes are either undeforming or extending [Mercier et al., 1992; Cladouhos et al., 1994; Lamb, 2000], implying that the buoyancy forces slightly over-estimate the horizontal force acting through the foreland lithosphere. The forces estimated in this study are consistent with previous results for central Peru $\left(2.5-5.0 \times 10^{12} \mathrm{~N} / \mathrm{m}\right.$; see Dalmayrac and Molnar [1981] and Richardson and Coblentz [1994]) and for the Bolivian Altiplano (3.0-6.0×10 $12 \mathrm{~N} / \mathrm{m}$; see Lamb [2000] and Oncken et al. $[2012])$.

Faults in the forelands will only break in earthquakes if their static frictional resistance to slip is overcome. Therefore, a bound on $\mu^{\prime}$ on faults along the margins of the northern and south-central Andes can be estimated from the condition that the horizontal force supported by the foreland seismogenic layer $F_{s l}$ must be less than $F_{f}$ in these regions [e.g. Copley et al., 2011]. The value of $\mu^{\prime}$ represents the effective coefficient of friction averaged over the fault plane and will be an upper bound, as shear zones beneath the brittle faults will also support some of the force acting through the lithosphere.

The horizontal force that can be transmitted through the seismogenic layer of thickness $T_{s}$ that contains faults that dip at an angle $\theta$ relative to the vertical is given by [Turcotte and Schubert, 2002]:

$$
F_{s l}=\frac{\mu^{\prime} \rho g T_{s}^{2}}{\sin 2 \theta-\mu^{\prime}(1+\cos 2 \theta)}
$$

where $g$ is the acceleration due to gravity and $\rho$ is the average density of the layer. Figure $4 \mathrm{~b}$ shows the predictions of Equation 1 plotted against estimates of $F_{f}$ and $T_{s}$ for the eight different regions of the Andes. In the regions where the foreland seismogenic layer is breaking up in compressional earthquakes on inherited normal faults (Colombia, Ecuador, northern Peru, central Peru and the Puna/Sierra Pampeanas of Argentina), Figure 4b demonstrates that the effective coefficient of friction 
on these inherited faults is consistently $\mu^{\prime}<0.2$, and may well be $\lesssim 0.1$. This is equivalent to the faults supporting average shear stresses $\bar{\tau}<150 \mathrm{MPa}$ in regions with a $45 \mathrm{~km}$ thick seismogenic layer and $<$ $100 \mathrm{MPa}$ in regions with a $30 \mathrm{~km}$ thick seismogenic layer. If the faults were any stronger, the forces acting through the foreland would not be large enough to overcome the frictional resistance to slip and break the seismogenic layer in compressional earthquakes. Notably, where the foreland deformation consists of compressional earthquakes throughout the seismogenic layer, areas with a thicker foreland seismogenic layer support the higher mountain ranges [Maggi et al., 2000a].

Around the margins of central Andean plateau in south Peru and Bolivia, where there are no preexisting normal faults and the foreland is being thrust beneath the mountain range, the relationship between $F_{f}$ and $T_{s}$ is less clear (Figure 4b). It is possible that in these regions either: (1) the seismogenic layer is thicker than estimated by the deepest earthquakes, (2) that $\mu^{\prime}$ on any faults is larger than $\sim 0.1-0.2$, or (3) that any faults present may be severely mis-oriented relative to the range front strike for re-activation (Figure 4b) [e.g. Sibson, 1995]. All of these mechanisms would lead to a seismogenic layer that is stronger than the forces acting through the foreland, meaning that the layer is thrust coherently beneath the plateau, as opposed to breaking up through slip on faults. With this configuration of deformation the force transmitted into the mountain range is no longer limited by faults within the foreland lithosphere, but by the strength of faults along the top of the underthrusting foreland and the viscosity of the plateau interior [Babeyko and Sobolev, 2005; Sobolev and Babeyko, $2005]$.

Many of the earthquakes in the forelands of the northern and south-central Andes are $M_{w} 5-6$ and do not necessarily break the full seismogenic layer at any one time. In the locations of these smallermagnitude earthquakes, the forces acting through the lithosphere may get focused onto strong asperities, whilst the remainder of the fault zone supports shear stresses well below the frictional resistance to slip. The force required to break an asperity with down-dip width $W$ and centroid depth $z_{c}$ can be calculated from Equation 1 by replacing the $T_{s}^{2}$ term with $2 z_{c} W \cos \theta$. Even in the extreme case where all of the force acting through the foreland $F_{f}$ is focused onto the rupture area of a foreland earthquake, the constraints on the size of this force require that $\mu^{\prime} \lesssim 0.3-0.4$ in order to generate the $M_{w} \sim 6$ earthquakes near the base of the 30-45 km thick seismogenic layer (Figure 4c). However, the extreme differences in the stress state in the seismogenic layer assumed by this model are unlikely given that strain must accumulate relatively evenly throughout the layer to load and break the faults, and to account for the frequent earthquakes over the seismogenic layer's entire thickness (Figure 4d).

A key result from this analysis is that the size of $F_{f}$ does not necessarily dictate the style of deformation 
within the foreland. The foreland seismogenic layer is breaking up in compressional earthquakes both where $F_{f}$ is its highest (Sierra Pampeanas, central Peru) and its lowest (Ecuador, Colombia). The lack of correlation between $F_{f}$ and the deformation style implies that enhanced mechanical coupling between the subducting Nazca Plate and overriding South American lithosphere, which is included implicitly in the force-balance analysis [e.g. Husson and Ricard, 2004], does not appear to influence the depth extent or pattern of seismicity in the forelands of the Andes.

\section{A Dry, Metastable Lower Crust Beneath the Andean Forelands}

The frictionally-weak faults within the forelands of the northern and south-central Andes remain seismogenic throughout the crust. In this section, I discuss how the depth extent of the seismicity, and the geological history of the inverted rift basins in the forelands, can be used to place constraints on the properties of the lower crust through which these weak faults cut.

A re-assessment of the depth distribution of earthquakes within the continents revealed a bi-modal pattern that depends on the geological history of the region [Maggi et al., 2000b; Jackson, 2002b]. Within the young mobile belts (e.g. Tibet, the Aegean, the Basin and Range) faults only remain seismogenic to depths of 10-20 km [Maggi et al., 2000b]. The depth extent of seismicity in these settings is thought to be limited by the onset of thermally-activated creep in hydrated, quartz-dominated rocks at temperatures of $300-400{ }^{\circ} \mathrm{C}$ [Sibson, 1982]. However, within the Precambrian shield systems that have resisted significant deformation through most of the Phanerozoic (e.g. India, Eurasia, South America), seismicity occurs to depths of 40-60 km, extending through the lower crust and, occasionally, into the upper mantle [Maggi et al., 2000b; Craig et al., 2011; Sloan et al., 2011]. Temperatures within the seismogenic lower crust of the Precambrian shields are $400-600{ }^{\circ} \mathrm{C}$ [McKenzie et al., 2005]. Therefore, rocks in the lower crust beneath the Precambrian shields remain seismogenic and mechanically strong, in as much as they resist penetrative deformation and can accumulate and release elastic strain over hundreds of years, to far higher temperatures than beneath the young mobile belts, suggesting that there is some compositional difference between these regions that accounts for their contrasting mechanical properties.

Jackson et al. [2004] argued that the lower crust beneath and along the margins of the Precambrian shields can remain seismogenic at such high temperature because of its anhydrous ('dry') mineralogy. Where sections of the Precambrian lower crust outcrop at the surface, they are typically formed of dry, granulite-facies rocks [Fountain and Salisbury, 1981]. These ancient granulites formed as a result of 
high-temperature $\left(>800-900{ }^{\circ} \mathrm{C}\right)$ metamorphism, possibly during mountain building [McKenzie and Priestley, 2016], that stripped the rocks of hydrous minerals through melting [Burton and O'Nions, 1990], leaving behind an anhydrous, load-bearing mineral assemblage of mainly feldspars and pyroxenes. Psuedotachylytes provide evidence that dry granulite can be seismogenic at lower-crustal conditions [Lund et al., 2004; Hawemann et al., 2018], but even trace amounts of water ingress into these rocks leads to viscous creep and mylonite formation that overprints the ancient granulitic fabrics [Austrheim and Boundy, 1994; Menegon et al., 2017]. These field observations are consistent with laboratory experiments that show the creep strength of feldspars and pyroxenes is drastically reduced by a few hundredths of a weight percent of structurally-bound water at lower-crustal temperatures [Mackwell et al., 1998; Rybacki and Dresen, 2004]. Therefore, a seismogenic lower crust, like that beneath the Andean forelands, is often considered to be a proxy for a dry, granulitic lower crust [Sloan et al., 2011; Craig and Jackson, 2021].

The geological history of the crust beneath the Andean forelands can be inferred from inliers and basement-cored reverse faults. Much of this exposed basement is Mesoproterozoic in age [Ramos, 2010a] and has experienced multiple episodes of penetrative deformation and regional metamorphism associated with mountain building and rifting along the western margin of South America [e.g. Rapela et al., 1998]. The best-exposed foreland basement can be found in the Sierra Pampeanas, where the most recent high-grade metamorphism and granitic magmatism is dated to two major mountain building episodes in the Cambrian (the Pampean orogeny) and Ordovician-Silurian (the Famatinian orogeny) [Rapela et al., 2010]. These orogenies led to granulite-facies metamorphism and melting in the rocks now exposed at the surface, and therefore it is likely the same regional metamorphism will have led to the conditions necessary to form dry, granulitic rocks in the underlying lower crust, which is currently breaking in earthquakes.

Xenoliths provide the most direct evidence for the composition of the lower crust where it is currently seismogenic. The only xenoliths with a clear eruptive origin from the foreland lower crust are found within late Cretaceous basalts that are inter-bedded with the syn-rift sediments of the Metán-Alemania Basin - a sub-basin of the western branch of the Salta Rift [Lucassen et al., 1999] (see Figure 3a for location). The xenolith suite consists of pristine felsic and mafic granulites that equilibrated at temperatures of $800-900{ }^{\circ} \mathrm{C}$ and pressures of $0.95-1.05 \mathrm{GPa}$ (equivalent to a depth of $\sim 34-38 \mathrm{~km}$ ). Peridotite xenoliths in the same suite also record temperatures of $1000-1200{ }^{\circ} \mathrm{C}$ at pressures of $1.2-1.6$ GPa in the shallow lithospheric mantle [Lucassen et al., 2005]. Whole-rock Sm-Nd ages of the crustal xenoliths are 80-90 Ma, which are thought to date the timing of their exhumation during syn-rift 
volcanism [Lucassen et al., 1999]. These observations suggest that, in the same depth range there is present-day seismicity beneath the Salta Rift, the lower crust was at granulite-facies conditions in the late Cretaceous (see Figure 2 for depth-range comparison).

Present-day conditions within the lower crust beneath the Salta Rift will be lower in pressure and temperature than those during rifting, as a result of the thinning of the radiogenic crust and conductive cooling of the lithosphere [Sandiford and Powell, 1986]. To estimate the evolution of the $P-T$ conditions beneath the Salta Rift, I ran a series of numerical calculations that simulate the late Cretaceous rifting and subsequent post-rift cooling based on the 1-D thermo-kinematic numerical model of Bown and White [1995] (see Supplementary Text S2 for details of the model set-up). I used a grid-search approach to find models that matched the $P-T-t$ constraints from xenolith thermobarometry, the history of synand post-rift sedimentation within the Metán-Alemania basin [Salfity and Marquillas, 1994; Starck, 2010], and the present-day crust and lithospheric mantle thickness. I then used the models that fit these varied data to explore the possible $P-T-t$ evolution of the seismogenic lower crust (Figure 5).

During rifting, the geotherm was perturbed away from a steady state and rocks were advected towards the surface causing a pressure decrease $(\Delta P)$. The amplitude of $\Delta P$ is controlled primarily by the amount of crustal stretching. At this time the lower crust was hot enough to undergo the dehydrationmelting reactions necessary to form granulite-facies rocks at depths of $\sim 35 \mathrm{~km}$ (Figure $5 \mathrm{a}$ ). The high lower-crustal temperatures could be achieved in the modelling by significant syn-rift thinning of the lithospheric mantle [e.g. Hopper et al., 2020], or an initially hot geotherm due to a thick radiogenic crust or thin lithospheric mantle. However, the limited amount of felsic magmatism recorded within the syn-rift sediments [Salfity and Marquillas, 1994] implies that the lower crust was already mostly dry by the Cretaceous in order to avoid widespread melting. Subsequent post-rift cooling over $\sim 80-90$ Myrs led to a decrease in temperature $(\Delta T)$ throughout the lower crust. For rocks exhumed to a depth of $35 \mathrm{~km}$, the models estimate that $\Delta T=75-250{ }^{\circ} \mathrm{C}$ and $\Delta P=0.15-0.25 \mathrm{GPa}$ (Figure $5 \mathrm{~b}, \mathrm{c}$ ). Estimates of the present-day temperatures at $35 \mathrm{~km}$ depth beneath the Salta Rift are $600-700{ }^{\circ} \mathrm{C}$ (Figure 5a), with the lower crust still cooling towards steady state.

The xenolith data and rift models suggest that, if the lower crust beneath the western branch of the Salta Rift was not already formed of dry granulite, then the $P-T$ conditions in the late Cretaceous will have led to widespread granulite-facies metamorphism. A modern analogue of the Cretaceous Salta Rift may be the Rio Grande Rift, where young crustal xenoliths also record granulite-facies conditions at the base of the lower crust [Cipar et al., 2020]. The lower crust has subsequently cooled to amphibolite-facies conditions. Despite the significant changes in $P$ and $T$, the dry granulites within 
the lower crust are likely to have remained metastable, as the possible retrograde reactions have sluggish kinetics in the absence of the volatiles that were driven off by melting and melt segregation along their prograde path [Brown, 2002]. The geological evolution of the Salta Rift is therefore consistent with the view that, where the lower crust is seismogenic along the margins of the Andes, it is formed of dry, granulitic rocks that preserve a metastable mineral assemblage [Jackson et al., 2021]. Nonetheless, more xenolith data that sample sections of the foreland lower crust along the remainder of the Andean range front are needed to rigorously test this hypothesis.

\section{Discussion}

\subsection{Structural Inheritance and Mountain Building in the Andes}

Watts et al. [1995] first recognised that there is a link between the pattern of active deformation along the margins of the Andes, the mechanical properties of the foreland lithosphere and the firstorder shape of the high mountains. They demonstrated that foreland lithosphere surrounding the wide and curved central Andean plateau has a high effective elastic thickness and is overlain by a thin-skinned fold-thrust belt that has accommodated extensive $(60-120 \mathrm{~km})$ Late Miocene-Recent shortening. In contrast, the narrow and linear ranges of the northern and south-central Andes have a foreland lithosphere with a lower effective elastic thickness that is breaking up along steeply-dipping faults that have accommodated less Late Miocene-Recent shortening [see also Kley and Monaldi, 1998; Oncken et al., 2006]. These observations led Watts et al. [1995] to suggest that along-strike differences in the mechanical properties of the foreland lithosphere control the style of deformation in the forelands, and that these variations in deformation style may, in turn, have influenced the Late Miocene-Recent growth of the Andes.

This study provides new insight into how the mechanical properties of the foreland lithosphere and the style of active deformation are linked. I have shown that, where Mesozoic rifts lie along the range front in the northern and south-central Andes, the foreland crust is highly seismogenic and is deforming entirely in compressional earthquakes (Figure 6, top). Frictionally-weak faults inherited from the rifts cut through the crust and are accommodating a significant component of the shortening, though these faults can be obscured at the surface by aseismic fold-thrust belts formed in the sedimentary cover (e.g. Marañon basin of central Peru). In contrast, where the Mesozoic rifts are absent from beneath the range front around the central Andean plateau, the foreland crust has experienced far 
fewer earthquakes, which mainly have shallow thrust-faulting mechanisms beneath the range front and normal-faulting mechanisms further into the foreland. The seismicity around the plateau is consistent with the view that the foreland seismogenic layer is too strong to break up in compression, so is bending and underthrusting the mountain range coherently beneath a low-angle décollement [Allmendinger and Gubbels, 1996] (Figure 6, bottom). Whether the forelands of the Andes can break up, or whether they underthrust the mountains, is therefore controlled by the effects of Mesozoic rifting on the mechanical properties of the foreland seismogenic layer.

Notably, the thickness of the seismogenic layer in the forelands does not correlate with the deformation style (see Section 4). Therefore, the thermal effects of Mesozoic rifting [e.g. Stewart and Watts, 1997] or Miocene-Pliocene volcanism [e.g. Ramos et al., 2002] do not appear to have created a thinner seismogenic layer in the northern and south-central Andes that is easier to break. Similarly, alongstrike changes in the thickness of the foreland lithosphere determined from surface-wave tomography [e.g. Priestley and McKenzie, 2013; Celli et al., 2020] do not appear to correlate with the deformation style (Supplementary Figure 3). Although, the horizontal resolution of the tomography ( 100-300 $\mathrm{km}$ ), and the possibility of horizontal smearing of velocity anomalies associated with the subducting Nazca Plate, precludes any confident comparison of lithospheric thickness and deformation style. The explanation that is most consistent with the observations available is that Mesozoic rifting formed or reactivated frictionally-weak, range-parallel faults along the western margin of the Precambrian shields and accreted terranes of South America. As these regions are shortened, the presence or absence of weak faults that are well-oriented relative to the range front for failure control the strength of the seismogenic layer and therefore the style of foreland deformation. The presence of mechanically-weak sediments on top of the foreland basement [Allmendinger and Gubbels, 1996] and viscous resistance to underthrusting beneath the Andes [Babeyko and Sobolev, 2005] may play a secondary role in controlling the style of foreland deformation.

\subsection{Weak, Seismogenic Faults in a Dry Lower Crust}

The force-balance calculations presented in Section 4 demonstrated that faults within the forelands of the northern and south-central Andes are frictionally-weak compared to laboratory experiments of static friction, and yet remain able to generate earthquakes at unusually high temperatures of $\sim 400-700{ }^{\circ} \mathrm{C}$ in the lower crust. The lower crust is thought to be extremely dry in order to remain seismogenic at such high temperatures [Jackson et al., 2004]. Two mechanisms have been invoked to account for frictionally-weak faults in the upper crust: (1) highly-pressurised water within the 
fault core, and (2) intrinsically-weak phyllosilicate minerals within faults that are produced through water-mediated alteration of the fault rock. In this section, I critically assess whether the same, watermediated mechanisms weakening faults in the upper crust could control the frictional properties of seismogenic faults in the lower crust.

Firstly, the dry and granulitic wall rocks inferred to surround faults in the forelands of the Andes will be metastable at lower-crustal conditions, and will readily react with free water to form new, stable mineral assemblages. The composition of the lower crust should therefore act as a sink of water and buffer the water pressure to far below lithostatic over time, except in regions of pervasive water influx and retrogression [Yardley and Valley, 1997]. The rates of hydration reactions from natural analogues suggest water can be consumed by dry granulitic rocks at mid-crustal temperature conditions at $\sim 10^{-8}$ $\mathrm{g} / \mathrm{cm}^{2} / \mathrm{s}$ [Whyte et al., 2021]. Without some mechanism that can isolate free water within the fault core from the reactive wall rocks, it is therefore unlikely that a pervasive water phase within the fault zone at $60-80 \%$ of lithostatic pressure is the cause of the frictionally-weak faults in the lower crust.

If water influx does occur into a fault zone formed of dry granulite at amphibolite-facies conditions, it will lead to water-consuming reactions that form hydrous minerals, particularly amphiboles and phyllosilicates [e.g. Beach, 1976; Andersen et al., 1991]. A common feature of exhumed granulite terrains are shear zones that contain aligned hydrous minerals surrounded by anhydrous wall rocks that preserve ancient fabrics [e.g. Sørensen, 1983; Newton, 1990; Austrheim and Boundy, 1994; Getsinger et al., 2013; Menegon et al., 2017]. This widespread observation implies that water ingress into fault zones during deformation leads to localised reaction softening along the fault and the onset of viscous creep at lower-crustal conditions, precluding the accumulation of elastic strain and frictional slip. The seismogenic fault zones in the Andean forelands are interpreted to have been re-activated following Mesozoic rifting, and presumably have a protracted history of deformation over millions of years that would have caused localised water ingress and reaction softening if there was water available in the lower crust. Therefore an alternative, water-absent mechanism may be necessary to account for the frictional properties of faults within the lower crust of the Andean forelands. Below I discuss some possible alternatives.

Shear zones within lower-crustal terrains often form networks of fine-grained or hydrated rocks in outcrop that wrap around rigid, undeformed blocks [e.g. Sørensen, 1983]. It is possible that earthquakes nucleate at stress concentrations in these mechanically heterogeneous fault zones by rupturing the rigid blocks (Figure 6, box 1). Although this mechanism can certainly account for small earthquakes [Campbell et al., 2020], for moderate-magnitude earthquakes with kilometre-sized rupture areas like 
those in the Andean forelands, even if all of the force acting through the lithosphere were focused onto the rupture area, the faults must still have an effective coefficient of friction less than half that predicted by Byerlee's Law (see the calculations presented in Section 4). Otherwise, the faults within the rigid blocks would be too strong to break, given the constraints on the size of the force acting through the foreland lithosphere.

Alternatively, fluids rich in non-hydrous volatile phases (e.g. $\mathrm{N}_{2}, \mathrm{CO}_{2}$ ) may be present as intergranular films and in pores in lower-crustal fault zones [Andersen et al., 1990]. Non-hydrous volatiles can reduce the activity of water in any fluid that may exist, which helps stabilise the anhydrous mineral assemblage of granulites that is needed for elastic strain to accumulate at high temperatures. The volatiles may also become highly-pressurised through deformation compaction and reduce the effective stresses within the fault zone without lowering the creep strength of the rock (Figure 6, box 2). Few experimental constraints exist on the influence of non-hydrous volatiles on creep in silicate minerals, which limits any quantitative test of this mechanism. Nonetheless, evidence from exhumed psuedotachylytes suggest that $\mathrm{CO}_{2}$-rich fluids are associated with frictional slip in mafic granulites at lower-crustal conditions [Sørensen et al., 2019].

It is also possible that the conditions under which friction is measured in the laboratory are just too far removed from those experienced by lower-crustal fault zones, and that dry fault rocks are intrinsically frictionally-weak at high confining pressures and temperatures (Figure 6, box 3). For example, if frictional resistance is governed by microscopic surface roughness, then the high temperatures and long inter-event times in the lower crust may allow asperities on fault surfaces to relax through localised creep, producing smooth and frictionally-weak faults. This explanation circumvents the need for a free fluid phase all together, and would account for the observation that psuedotachylytes can occur in completely dry lower-crustal rocks [Hawemann et al., 2019; Dunkel et al., 2021]. However, the same asperity relaxation effects have been shown to cause a transition from velocity-weakening (i.e. seismogenic) to velocity-strengthening (i.e. aseismic) slip behaviour in olivine aggregates deformed at high temperatures [Boettcher et al., 2007], which may in fact preclude lower-crustal seismicity.

It therefore remains unclear which, if any, of these mechanisms may account for the frictional properties of faults in the Andean forelands. Testing the different hypotheses shown in Figure 6 using geological observations is difficult, as the various mechanisms are highly dependent on the mineralogy, fluid availability and fluid composition, which will all vary along the fault. In contrast, the geophysical constraints developed in this study reflect fault-averaged frictional properties over lengthscales of kilometres, which undoubtedly smooth out complex, outcrop-scale structure and processes. 
Further measurements of the frictional strength of faults in various geological settings, with different deformation rates and over different length-scale are needed to understand what controls their effective strength. Nonetheless, a few simple conclusions regarding the mechanics of lower-crustal fault zones can be drawn from this discussion: (1) frictionally-weak faults may remain seismogenic in the continental lower crust after multiple episodes of reactivation separated by millions of years, and (2) water-assisted weakening mechanisms like those inferred to be active in the upper crust are unlikely to operate on seismogenic, lower-crustal faults if they are surrounded by dry and metastable rocks.

\section{Conclusions}

I have shown that the distribution of seismicity along the margin of the Andes is correlated with the locus of Mesozoic rift systems that stretched the foreland lithosphere prior to the Andean orogeny. Where the rift systems lie along the margins of the mountain belt, the whole 30-45 km-thick seismogenic layer is shortening by slip on inherited normal faults. Where these inherited faults are absent, or mis-oriented relative to the shortening direction, the foreland is bending and being underthrust beneath the Andes. I have estimated the forces acting on the inherited faults, and demonstrated that they have an effective coefficient of static friction $\mu^{\prime}<0.2$, which is significantly lower than predicted by laboratory experiments. The mechanisms that have been proposed to generate weak, seismogenic faults in the upper crust are typically related to a free water-phase. I argue that these water-assisted mechanisms alone are unlikely to weaken faults in the seismogenic lower crust due to its dry, granulitic composition and the effect of water on viscous creep mechanisms at high temperatures. Therefore, although the frictional properties of faults within the Andean forelands appear to be important in controlling the style of mountain building, the geological controls on their mechanical properties remain enigmatic.

\section{Acknowledgements}

SW was supported by the Denman Baynes Junior Research Fellowship at Clare College, Cambridge. SW thanks Alex Copley, Carlos Benavente, David Wallis, Aisling O'Kane and Camilla Penney for discussions and comments on the manuscript. SW also acknowledges the constructive reviews of this manuscript by Tomas Capaldi and Simon Lamb, which helped to significantly improve the scope and clarity of the arguments presented here. 


\section{${ }_{595}$ Data Availability}

596 Waveform data used in this study was is freely available from the Incorporated Research Institute for

597 Seismology (IRIS) data management centre. The computer codes used to perform the force-balance calculations and the 1-D thermo-kinematic modelling are available from: https://github.com/ samwimpenny/forelands_2021. All earthquake focal mechanism data will be uploaded to the gWFM catalogue available at: https://comet.nerc.ac.uk/gwfm_catalogue/gWFM_catalogue.html 


\section{References}

Allmendinger, R. and Gubbels, T. (1996). Pure and simple shear plateau uplift, Altiplano-Puna, Argentina and Bolivia. Tectonophysics, 259(1-3):1-13.

Alvarado, A., Audin, L., Nocquet, J. M., Lagreulet, S., Segovia, M., Font, Y., Lamarque, G., Yepes, H., Mothes, P., Rolandone, F., Jarrín, P., and Quidelleur, X. (2014). Active tectonics in Quito, Ecuador, assessed by geomorphological studies, GPS data, and crustal seismicity. Tectonics, 33(2):67-83.

Alvarado, P. and Beck, S. (2006). Source characterization of the San Juan (Argentina) crustal earthquakes of 15 January 1944 ( $\mathrm{Mw}$ 7.0) and 11 June 1952 (Mw 6.8). Earth and Planetary Science Letters, 243(3-4):615-632.

Alvarado, P., Beck, S., Zandt, G., Araujo, M., Triep, E., Isacks, B. L., Araujo, M., Puebla, N. P., and Sistena, J. A. (2005). Crustal deformation in the south-central Andes backarc terranes as viewed from regional broad-band seismic waveform modelling. Geophysical Journal International, 163(2):580-598.

Andersen, T., Austrheim, H., and Burke, E. A. (1991). Fluid-induced retrogression of granulites in the Bergen Arcs, Caledonides of W. Norway: Fluid inclusion evidence from amphibolite-facies shear zones. LITHOS, 27(1):29-42.

Andersen, T., Austrheim, H., and Burke, E. A. J. (1990). Fluid inclusions in granulites and eclogites from the Bergen Arcs, Caledonides of W. Norway. Mineralogical Magazine, 54(375):145-158.

Assumpção, M. and Araujo, M. (1993). Effect of the Altiplano-Puna plateau, South America, on the regional intraplate stresses. Tectonophysics, 221(3-4):475-496.

Assumpção, M., Feng, M., Tassara, A., and Julià, J. (2013). Models of crustal thickness for South America from seismic refraction, receiver functions and surface wave tomography. Tectonophysics, 609:82-96.

Assumpção, M. and Suarez, G. (1988). Source mechanisms of moderate-size earthquakes and stress orientation in mid-plate South America. Geophysical Journal International, 92(2):253-267.

Austrheim, H. and Boundy, T. M. (1994). Pseudotachylytes generated during seismic faulting and eclogitization of the deep crust. Science, 265(5168):82-83.

Babeyko, A. Y. and Sobolev, S. V. (2005). Quantifying different modes of the late Cenozoic shortening in the central Andes. Geology, 33(8):621-624. 
Barke, R., Lamb, S., and MacNiocaill, C. (2007). Late Cenozoic bending of the Bolivian Andes: New paleomagnetic and kinematic constraints. Journal of Geophysical Research: Solid Earth, 112(1):122.

Beach, A. (1976). The Interrelations of Fluid Transport, Deformation, Geochemistry and Heat Flow in Early Proterozoic Shear Zones in the Lewisian Complex Author ( s ): A . Beach Source : Philosophical Transactions of the Royal Society of London . Series A, Mathematical. Philosophical Transactions of the Royal Society A, 280(1298):569-604.

Boettcher, M. S., Hirth, G., and Evans, B. (2007). Olivine friction at the base of oceanic seismogenic zones. Journal of Geophysical Research: Solid Earth, 112(1):1-13.

Bown, J. W. and White, R. S. (1995). Effect of finite extension rate on melt generation at rifted continental margins. Journal of Geophysical Research, 100(B9):18011-18029.

Brooks, B. a., Bevis, M., Whipple, K., Ramon Arrowsmith, J., Foster, J., Zapata, T., Kendrick, E., Minaya, E., Echalar, A., Blanco, M., Euillades, P., Sandoval, M., and Smalley, R. J. (2011). Orogenic-wedge deformation and potential for great earthquakes in the central Andean backarc. Nature Geoscience, 4(6):380-383.

Brown, M. (2002). Retrograde processes in migmatites and granulites revisited. Journal of Metamorphic Geology, 20(1):25-40.

Burton, K. W. and O'Nions, R. K. (1990). The timescale and mechanism of granulite formation at Kurunegala, Sri Lanka. Contributions to Mineralogy and Petrology, 106(1):66-89.

Butler, R. W., Tavarnelli, E., and Grasso, M. (2006). Structural inheritance in mountain belts: An Alpine-Apennine perspective. Journal of Structural Geology, 28(11):1893-1908.

Byerlee, J. (1978). Friction of rocks. Pure and Applied Geophysics, 116(4-5):615-626.

Cahill, T., Isacks, B. L., Whitman, D., Chatelain, J. ., Perez, A., and Chiu, J. M. (1992). Seismicity and tectonics in Jujuy Province, northwestern Argentina. Tectonics, 11(5):944-959.

Campbell, L. R., Menegon, L., Fagereng, and Pennacchioni, G. (2020). Earthquake nucleation in the lower crust by local stress amplification. Nature Communications, 11(1):1-9.

Celli, N. L., Lebedev, S., Schaeffer, A. J., Ravenna, M., and Gaina, C. (2020). The upper mantle beneath the South Atlantic Ocean, South America and Africa from waveform tomography with massive data sets. Geophysical Journal International, 221(1):178-204. 
Charrier, R., Ramos, V. A., Tapia, F., and Sagripanti, L. (2015). Tectono-stratigraphic evolution of the Andean Orogen between 31 and 37S (Chile and Western Argentina). Geological Society Special Publication, 399:13-61.

Chinn, D. S. and Isacks, B. L. (1983). Accurate source depths and focal mechanisms of shallow earthquakes in western South America and in the New Hebrides Island Arc. Tectonics, 2(6):529563.

Cipar, J. H., Garber, J. M., Kylander-Clark, A. R., and Smye, A. J. (2020). Active crustal differentiation beneath the Rio Grande Rift. Nature Geoscience, 13(11):758-763.

Cladouhos, T. T., Allmendinger, R. W., Coira, B., and Farrar, E. (1994). Late cenozoic deformation in the Central Andes: fault kinematics from the northern Puna, northwestern Argentina and southwestern Bolivia. Journal of South American Earth Sciences, 7(2):209-228.

Coira, B., Davidson, J., Mpodozis, C., and Ramos, V. (1982). Tectonic and magmatic evolution of the Andes of northern Argentina and Chile. Earth Science Reviews, 18(3-4):303-332.

Collettini, C., Tesei, T., Scuderi, M. M., Carpenter, B. M., and Viti, C. (2019). Beyond Byerlee friction, weak faults and implications for slip behavior. Earth and Planetary Science Letters, 519:245-263.

Condori, C., França, G. S., Tavera, H. J., Albuquerque, D. F., Bishop, B. T., and Beck, S. L. (2017). Crustal structure of north Peru from analysis of teleseismic receiver functions. Journal of South American Earth Sciences, 76:11-24.

Copley, A. (2018). The strength of earthquake-generating faults. Journal of the Geological Society, $174(1)$.

Copley, A., Avouac, J.-P., Hollingsworth, J., and Leprince, S. (2011). The 2001 Mw 7.6 Bhuj earthquake, low fault friction, and the crustal support of plate driving forces in India. Journal of Geophysical Research: Solid Earth, 116(B8):B08405.

Copley, A. and Woodcock, N. (2016). Estimates of fault strength from the Variscan foreland of the northern UK. Earth and Planetary Science Letters, 451:108-113.

Craig, T. J., Copley, A., and Jackson, J. A. (2012). Thermal and tectonic consequences of India underthrusting Tibet. Earth and Planetary Science Letters, 353-354:231-239.

Craig, T. J. and Jackson, J. A. (2021). Variations in the Seismogenic Thickness of East Africa. Journal of Geophysical Research: Solid Earth, 126(3):e2020JB020754. 
Craig, T. J., Jackson, J. A., Priestley, K., and McKenzie, D. (2011). Earthquake distribution patterns in Africa: their relationship to variations in lithospheric and geological structure, and their rheological implications. Geophysical Journal International, 185(1):403-434.

Dalmayrac, B. and Molnar, P. (1981). Parallel thrust and normal faulting in Peru and constraints on the state of stress. Earth and Planetary Science Letters, 55(3):473-481.

Devlin, S., Isacks, B. L., Pritchard, M. E., Barnhart, W. D., and Lohman, R. B. (2012). Depths and focal mechanisms of crustal earthquakes in the central Andes determined from teleseismic waveform analysis and InSAR. Tectonics, 31(2):1-33.

Dimate, C., Rivera, L., Taboada, A., Delouis, B., Osorio, A., Jimenez, E., Fuenzalida, A., Cisternas, A., and Gomez, I. (2003). The 19 January 1995 Tauramena (Colombia) earthquake: Geometry and stress regime. Tectonophysics, 363(3-4):159-180.

Dorbath, C., Dorbath, L., Cisternas, A., Deverchere, J., Diament, M., Ocola, L., and Morales, M. (1986). On crustal seismicity of the Amazonian foothill of the central Peruvian Andes. Geophysical Research Letters, 13(10):1023-1026.

Dunkel, K. G., Zhong, X., Arnestad, P. F., Valen, L. V., and Jamtveit, B. (2021). High Transient Stress in The Lower Crust: Evidence from Dry Pseudotachylytes in Granulites, Lofoten Archipelago, Northern Norway. Geology, 49(2):135-139.

Fountain, D. M. and Salisbury, M. H. (1981). Exposed cross-sections through the continental crust: implications for crustal structure, petrology, and evolution. Earth and Planetary Science Letters, $56(\mathrm{C}): 263-277$.

Getsinger, A. J., Hirth, G., Stünitz, H., and Goergen, E. T. (2013). Influence of water on rheology and strain localization in the lower continental crust. Geochemistry, Geophysics, Geosystems, $14(7): 2247-2264$.

Golonka, J., Lawver, L., Coffin, M., Dalziel, I. D., and Gahagan, L. (1995). Paleogeographic Reconstructions with Sediment Isopachs, PLATES progress report No. 104-0695. Technical report, University of Texas Institute for Geophysics.

Gubbels, T. L., Isacks, B. L., and Farrar, E. (1993). High-level surfaces, plateau uplift, and foreland development, Bolivian central Andes. Geology, 21(8):695. 
Gutscher, M.-A., Spakman, W., Bjiwaard, H., and Enghdahl, E. R. (2000). Geodynamics of flat subduction: Seismicity and tomographic constraints from the Andean margin. Tectonics, 19(5):814833.

Hawemann, F., Mancktelow, N. S., Pennacchioni, G., Wex, S., and Camacho, A. (2019). Weak and Slow, Strong and Fast: How Shear Zones Evolve in a Dry Continental Crust (Musgrave Ranges, Central Australia). Journal of Geophysical Research: Solid Earth, 124(1):219-240.

Hawemann, F., Mancktelow, N. S., Wex, S., Camacho, A., and Pennacchioni, G. (2018). Pseudotachylyte as field evidence for lower-crustal earthquakes during the intracontinental Petermann Orogeny (Musgrave Block, Central Australia). Solid Earth, 9(3):629-648.

Hayes, G. P., Moore, G. L., Portner, D. E., Hearne, M., Flamme, H., Furtney, M., and Smoczyk, G. M. (2018). Slab2, a comprehensive subduction zone geometry model. Science, 362(6410):58-61.

Hermoza, W., Brusset, S., Baby, P., Gil, W., Roddaz, M., Guerrero, N., and Bolaños, M. (2005). The Huallaga foreland basin evolution: Thrust propagation in a deltaic environment, northern Peruvian Andes. Journal of South American Earth Sciences, 19(1 SPEC. ISS.):21-34.

Hopper, E., Gaherty, J. B., Shillington, D. J., Accardo, N. J., Nyblade, A. A., Holtzman, B. K., Havlin, C., Scholz, C. A., Chindandali, P. R., Ferdinand, R. W., Mulibo, G. D., and Mbogoni, G. (2020). Preferential localized thinning of lithospheric mantle in the melt-poor Malawi Rift. Nature Geoscience, 13(8):584-589.

Hubbert, M. K. and Rubey, W. W. (1959). Mechanics of fluid-filled porous solids and its application to overthrust faulting. Bulletin of the Geological Society of America, 70(2):115-166.

Husson, L. and Ricard, Y. (2004). Stress balance above subduction: Application to the Andes. Earth and Planetary Science Letters, 222(3-4):1037-1050.

Imber, J., Holdsworth, R. E., Butler, C. A., and Lloyd, G. E. (1997). Fault-zone weakening processes along the reactivated Outer Hebrides Fault Zone, Scotland. Journal of the Geological Society, 154(1):105-109.

Jackson, J. (2002a). Faulting, flow, and the strength of the continental lithosphere. International Geology Review, 44(1):39-61.

Jackson, J., McKenzie, D., and Priestley, K. (2021). Relations between earthquake distributions, geological history, tectonics and rheology on the continents. Philosophical Transactions of the Royal Society A: Mathematical, Physical and Engineering Sciences, 379(2193). 
Jackson, J. A. (2002b). Strength of the continental lithosphere: Time to abandon the jelly sandwich? GSA Today, 12(9):4.

Jackson, J. A., Austrheim, H., McKenzie, D., and Priestley, K. (2004). Metastability, mechanical strength, and the support of mountain belts. Geology, 32(7):625.

Jordan, T. E., Isacks, B. 1., Allmendinger, R. E., Brewer, J. A., Ramos, V. A., and Ando, C. J. (1983). Andean tectonics related to geometry of subducted Nazca plate. Geological Society of America Bulletin, 94(3):341.

Kadinsky-Cade, K., Reilinger, R., and Isacks, B. (1985). Surface deformation associated with the November 23, 1977, Caucete, Argentina, earthquake sequence. Journal of Geophysical Research: Solid Earth, 90(14):12691-12700.

Kendrick, E., Bevis, M., Smalley, R., and Brooks, B. (2001). An integrated crustal velocity field for the central Andes. Geochemistry, Geophysics, Geosystems, 2.

Kendrick, E., Brooks, B. A., Bevis, M., Jr., R. S., Lauria, E., Araujo, M., and Parra, H. (2006). Orogenia activa de los Andes centro-australes estudiada mediante geodesia de GPS. Revista de la Asociación Geológica Argentina, 61(4):555-566.

Kennan, L., Lamb, S. H., and Hoke, L. (1997). High-altitude palaeosurfaces in the Bolivian Andes: evidence for late Cenozoic surface uplift. Geological Society, London, Special Publications, 120(1).

Kley, J. and Monaldi, C. R. (1998). Tectonic shortening and crustal thickness in the Central Andes: How good is the correlation? Geology, 26(8):723-726.

Kley, J. and Monaldi, C. R. (2002). Tectonic inversion in the Santa Barbara System of the central Andean foreland thrust belt, northwestern Argentina. Tectonics, 21(6):11-1-11-18.

Kley, J., Monaldi, C. R., and Salfity, J. A. (1999). Along-strike segmentation of the Andean foreland: Causes and consequences. Tectonophysics, 301(1-2):75-94.

Kley, J., Rossello, E. A., Monaldi, C. R., and Habighorst, B. (2005). Seismic and field evidence for selective inversion of Cretaceous normal faults, Salta rift, northwest Argentina. Tectonophysics, 399(1-4 SPEC. ISS.):155-172.

Kostrov, B. V. (1974). Seismic moment and energy of earthquakes, and seismic flow of rock. Physics of the Solid Earth, 1:13-21. 
Lamb, S. (2006). Shear stresses on megathrusts: Implications for mountain building behind subduction zones. Journal of Geophysical Research: Solid Earth, 111(B7):B07401.

Lamb, S. H. (2000). Active deformation in the Bolivian Andes, South America. Journal of Geophysical Research: Solid Earth, 105(B11):25627-25653.

Legrand, D., Baby, P., Bondoux, F., Dorbath, C., Bès de Berc, S., and Rivadeneira, M. (2005). The 1999-2000 seismic experiment of Macas swarm (Ecuador) in relation with rift inversion in Subandean foothills. Tectonophysics, 395(1-2):67-80.

Lucassen, F., Franz, G., Viramonte, J., Romer, R. L., Dulski, P., and Lang, A. (2005). The late Cretaceous lithospheric mantle beneath the Central Andes: Evidence from phase equilibria and composition of mantle xenoliths. Lithos, 82(3-4):379-406.

Lucassen, F., Lewerenz, S., Franz, G., Viramonte, J., and Mezger, K. (1999). Metamorphism, isotopic ages and composition of lower crustal granulite xenoliths from the Cretaceous Salta Rift, Argentina. Contributions to Mineralogy and Petrology, 134(4):325-341.

Lund, M. G., Austrheim, H., and Erambert, M. (2004). Earthquakes in the deep continental crust-insights from studies on exhumed high-pressure rocks. Geophysical Journal International, $158(2): 569-576$.

Lyon-Caen, H., Molnar, P., and Suárez, G. (1985). Gravity anomalies and flexure of the Brazilian Shield beneath the Bolivian Andes. Earth and Planetary Science Letters, 75(1):81-92.

Mackwell, S. J., Zimmerman, M. E., and Kohlstedt, D. L. (1998). High-temperature deformation of dry diabase with application to tectonics on Venus. Journal of Geophysical Research: Solid Earth, 103(1):975-984.

Maggi, A., Jackson, J. A., McKenzie, D., and Priestley, K. (2000a). Earthquake focal depths, effective elastic thickness, and the strength of the continental lithosphere. Geology, 28(6):495.

Maggi, A., Jackson, J. A., Priestley, K., and Baker, C. (2000b). A re-assessment of focal depth distributions in southern Iran, the Tien Shan and northern India: do earthquakes really occur in the continental mantle? Geophysical Journal International, 143(3):629-661.

Mathalone, J. M. P. and Montoya, M. R. (1995). Petroleum Geology of the Sub-Andean Basins of Peru. In Petroleum Basins of South America, pages 423-444. AAPG Special Volumes. 
McGroder, M. F., Lease, R. O., and Pearson, D. M. (2015). Along-strike variation in structural styles and hydrocarbon occurrences, Subandean fold-and-thrust belt and inner foreland, Colombia to Argentina. In DeCelles, P. G., Ducea, M. N., Carrapa, B., and Kapp, P. A., editors, Geodynamics of a Cordilleran Orogenic System: The Central Andes of Argentina and Northern Chile. Geological Society of America.

McKenzie, D., Jackson, J., and Priestley, K. (2005). Thermal structure of oceanic and continental lithosphere. Earth and Planetary Science Letters, 233(3):337-349.

McKenzie, D. and Priestley, K. (2016). Speculations on the formation of cratons and cratonic basins. Earth and Planetary Science Letters, 435:94-104.

Meigs, A. J. and Nabelek, J. (2010). Crustal-scale pure shear foreland deformation of western Argentina. Geophysical Research Letters, 37(11).

Menegon, L., Pennacchioni, G., Malaspina, N., Harris, K., and Wood, E. (2017). Earthquakes as Precursors of Ductile Shear Zones in the Dry and Strong Lower Crust. Geochemistry, Geophysics, Geosystems, 18(12):4356-4374.

Mercier, J. L., Sebrier, M., Lavenu, A., Cabrera, J., Bellier, O., Dumont, J.-F., and Machrare, J. (1992). Changes in the tectonic regime above a subduction zone of Andean Type: The Andes of Peru and Bolivia during the Pliocene-Pleistocene. Journal of Geophysical Research, 97(B8):11945.

Molnar, P., Chen, W.-P., Fitch, T. J., Tapponnier, P., Warsi, W. E. K., and Wu, F. (1977). Structure and Tectonics of the Himalaya: A brief summary of relevant geophysical observations. In Collogue Internationaux du CNRS, No. 268, Himalaya: Sciences de la Terre, pages 269-294, Paris. du Centre National de la Recherche Scientifique.

Molnar, P. and Lyon-Caen, H. (1988). Some simple physical aspects of the support, structure, and evolution of mountain belts. In Geological Society of America Special Papers, volume 218, pages 179-208. Geological Society of America.

Molnar, P. and Lyon-Caen, H. (1989). Fault plane solutions of earthquakes and active tectonics of the Tibetan Plateau and its margins. Geophysical Journal International, 99(1):123-154.

Mora, A., Parra, M., Strecker, M. R., Kammer, A., Dimaté, C., and Rodríguez, F. (2006). Cenozoic contractional reactivation of Mesozoic extensional structures in the Eastern Cordillera of Colombia. Tectonics, 25(2).

Newton, R. C. (1990). Fluids and shear zones in the deep crust. Tectonophysics, 182(1-2):21-37. 
Nocquet, J. M., Villegas-Lanza, J. C., Chlieh, M., Mothes, P. A., Rolandone, F., Jarrin, P., Cisneros, D., Alvarado, A., Audin, L., Bondoux, F., Martin, X., Font, Y., Régnier, M., Vallée, M., Tran, T., Beauval, C., Maguiña Mendoza, J. M., Martinez, W., Tavera, H., and Yepes, H. (2014). Motion of continental slivers and creeping subduction in the northern Andes. Nature Geoscience, 7(4):287-291.

Oncken, O., Boutelier, D., Dresen, G., and Schemmann, K. (2012). Strain accumulation controls failure of a plate boundary zone: Linking deformation of the Central Andes and lithosphere mechanics. Geochemistry, Geophysics, Geosystems, 13(12).

Oncken, O., Hindle, D., Kley, J., Elger, K., Victor, P., and Schemmann, K. (2006). Deformation of the Central Andean Upper Plate System Facts, Fiction, and Constraints for Plateau Models. In The Andes, pages 3-27. Springer Berlin Heidelberg.

Poveda, E., Monsalve, G., and Vargas, C. A. (2015). Receiver functions and crustal structure of the northwestern Andean region, Colombia. Journal of Geophysical Research: Solid Earth, 120(4):24082425 .

Priestley, K. and McKenzie, D. (2013). The relationship between shear wave velocity, temperature, attenuation and viscosity in the shallow part of the mantle. Earth and Planetary Science Letters, 381:78-91.

Ramos, V. A. (2009). Anatomy and global context of the Andes: Main geologic features and the Andean orogenic cycle. In Kay, S. M., Ramos, V. A., and Dickinson, W. R., editors, Backbone of the Americas: Shallow subduction, Plateau Uplift ad Terrane Collision, pages 31-65. Geological Society of America Memoir 204.

Ramos, V. A. (2010a). The Grenville-age basement of the Andes. Journal of South American Earth Sciences, 29(1):77-91.

Ramos, V. A. (2010b). The tectonic regime along the Andes: Present-day and Mesozoic regimes. Geological Journal, 45(1):2-25.

Ramos, V. A., Cristallini, E. O., and Pérez, D. J. (2002). The Pampean flat-slab of the Central Andes. Journal of South American Earth Sciences, 15(1):59-78.

Rapela, C. W., Pankhurst, R. J., Casquet, C., Baldo, E., Galindo, C., Fanning, C. M., and Dahlquist, J. M. (2010). The Western Sierras Pampeanas: Protracted Grenville-age history (1330-1030 Ma) of intra-oceanic arcs, subduction-accretion at continental-edge and AMCG intraplate magmatism. Journal of South American Earth Sciences, 29(1):105-127. 
Rapela, C. W., Pankhurst, R. J., Casquet, C., Baldo, E., Saavedra, J., Galindo, C., and Fanning, C. M. (1998). The Pampean Orogeny of the southern proto-Andes: Cambrian continental collision in the Sierras de Cordoba. Geological Society Special Publication, 142(i):181-217.

Richardson, R. M. and Coblentz, D. D. (1994). Stress modeling in the Andes: Constraints on the South American intraplate stress magnitudes. Journal of Geophysical Research: Solid Earth, 99(B11):22015-22025.

Richardson, T., Gilbert, H., Anderson, M., and Ridgway, K. D. (2012). Seismicity within the actively deforming Eastern Sierras Pampeanas, Argentina. Geophysical Journal International, 188(2):408420.

Rivas, C., Ortiz, G., Alvarado, P., Podesta, M., and Martin, A. (2019). Modern crustal seismicity in the northern Andean Precordillera, Argentina. Tectonophysics, 762(January):144-158.

Rybacki, E. and Dresen, G. (2004). Deformation mechanism maps for feldspar rocks. Tectonophysics, $382(3-4): 173-187$.

Salfity, J. A. and Marquillas, R. A. (1994). Tectonic and Sedimentary Evolution of the CretaceousEocene Salta Group Basin, Argentina. In Salfity, J. A., editor, Cretaceous Tectonics of the Andes, pages 266-315. Vieweg.

Sandiford, M. and Powell, R. (1986). Deep crustal metamorphism during continental extension: modern and ancient examples. Earth and Planetary Science Letters, 79(1-2):151-158.

Sempere, T., Carlier, G., Soler, P., Fornari, M., Carlotto, V., Jacay, J., Arispe, O., Néraudeau, D., Cárdenas, J., Rosas, S., and Jiménez, N. (2002). Late Permian-Middle Jurassic lithospheric thinning in Peru and Bolivia, and its bearing on Andean-age tectonics. Tectonophysics, 345(1-4):153-181.

Sibson, R. H. (1982). Fault zone models, heat flow, and the depth distribution of earthquakes in the continental crust of the United States. Bulletin of the Seismological Society of America, 72(1):151163.

Sibson, R. H. (1990). Conditions for fault-valve behaviour. Geological Society Special Publication, $54(1): 15-28$.

Sibson, R. H. (1995). Selective fault reactivation during basin inversion: Potential for fluid redistribution through fault-valve action. Geological Society Special Publication, 88(88):3-19. 
Sloan, R. A., Jackson, J. A., McKenzie, D., and Priestley, K. (2011). Earthquake depth distributions in central Asia, and their relations with lithosphere thickness, shortening and extension. Geophysical Journal International, 185(1):1-29.

Smalley, R. and Isacks, B. L. (1990). Seismotectonics of thin- and thick-skinned deformation in the Andean foreland from local network data: evidence for a seismogenic lower crust. Journal of Geophysical Research, 95(B8):12487-12498.

Smalley, R., Pujol, J., Regnier, M., Chiu, J. ., Chatelain, J. ., Isacks, B. L., Araujo, M., and Puebla, N. (1993). Basement seismicity beneath the Andean precordillera thinskinned thrust belt and implications for crustal and lithospheric behavior. Tectonics, 12(1):63-76.

Sobolev, S. and Babeyko, A. (2005). What drives orogeny in the Andes? Geology, 33(8):617-620.

Sørensen, B. E., Grant, T., Ryan, E. J., and Larsen, R. B. (2019). In situ evidence of earthquakes near the crust mantle boundary initiated by mantle $\mathrm{CO} 2$ fluxing and reaction-driven strain softening. Earth and Planetary Science Letters, 524:115713.

Sørensen, K. (1983). Growth and dynamics of the Nordre Stromfjord shear zone. Journal of Geophysical Research, 88(B4):3419-3437.

Spikings, R., Reitsma, M. J., Boekhout, F., Mišković, A., Ulianov, A., Chiaradia, M., Gerdes, A., and Schaltegger, U. (2016). Characterisation of Triassic rifting in Peru and implications for the early disassembly of western Pangaea. Gondwana Research, 35:124-143.

Starck, D. (2010). Cuenca Cretàcica-Paleógena Del Noroeste Argentino. In VIII Congreso de Exploración y Desarrollo de Hidrocarburos Simposio Cuencas Argentinas, pages 407-453, Instituto Argentino del Petróleo y el Gas.

Stewart, J. and Watts, A. B. (1997). Gravity anomalies and spatial variations of flexural rigidity at mountain ranges. Journal of Geophysical Research: Solid Earth, 102(B3):5327-5352.

Suárez, G., Gagnepain, J., Cisternas, A., Hatzfeld, D., Molnar, P., Ocola, L., Roecker, S. W., and Viodé, J. P. (1990). Tectonic deformation of the Andes and the configuration of the subducted slab in central Peru; results from a microseismic experiment. Geophysical Journal International, 103(1):1-12.

Suarez, G., Molnar, P., and Burchfiel, B. C. (1983). Seismicity, fault plane solutions, depth of faulting, and active tectonics of the Andes of Peru, Ecuador, and southern Colombia. Journal of Geophysical Research, 88(B12):10403-10428. 
Taymaz, T., Jackson, J. A., and Westaway, R. (1990). Earthquake mechanisms in the Hellenic Trench near Crete. Geophysical Journal International, 102(3):695-731.

Turcotte, D. L. and Schubert, G. (2002). Geodynamics. Cambridge University Press.

Vaca, S., Vallée, M., Nocquet, J. M., and Alvarado, A. (2019). Active deformation in Ecuador enlightened by a new waveform-based catalog of earthquake focal mechanisms. Journal of South American Earth Sciences, 93:449-461.

Watts, A., Lamb, S., Fairhead, J., and Dewey, J. (1995). Lithospheric flexure and bending of the Central Andes. Earth and Planetary Science Letters, 134(1-2):9-21.

Weiss, J. R., Brooks, B. A., Arrowsmith, J. R., and Vergani, G. (2015). Spatial and temporal distribution of deformation at the front of the Andean orogenic wedge in southern Bolivia. Journal of Geophysical Research: Solid Earth, 120(3):1909-1931.

Weller, O. M., Mottram, C. M., St-Onge, M. R., Möller, C., Strachan, R., Rivers, T., and Copley, A. (2021). The metamorphic and magmatic record of collisional orogens. Nature Reviews Earth $E$ Environment, pages 1-19.

Whyte, A. J., Weller, O. M., Copley, A. C., and St-Onge, M. R. (2021). Quantifying water diffusivity and metamorphic reaction rates within mountain belts, and their implications for the rheology of cratons. Geochemistry Geophysics Geosystems, n/a(n/a):n/a.

Wimpenny, S., Benavente, C., Copley, A., Garcia, B., Rossell, L., O’Kane, A., and Aguirre, E. (2020). Observations and Dynamical Implications of Active Normal Faulting in South Peru. Geophysical Journal International, 222(1):27-53.

Wimpenny, S., Copley, A., Benavente Escobar, C. L., and Aguirre, E. (2018). Extension and Dynamics of the Andes inferred from the 2016 Parina (Huarichancara) Earthquake. Journal of Geophysical Research: Solid Earth, 123(9):8198-8228.

Yardley, B. W. D. and Valley, J. W. (1997). The petrologic case for a dry lower crust. Journal of Geophysical Research, 102(97):12173-12185.

Zwick, P., McCaffrey, R., and Abers, G. (1994). MT5 Program. 


\section{Tables}

Table 1: Comparison of geodetic and seismic deformation rates in the Andean forelands.

\begin{tabular}{ccccccc}
\hline Location & $v_{x}[\mathrm{~mm} / \mathrm{yr}]$ & $W[\mathrm{~km}]$ & $\dot{\varepsilon}_{x x}^{g}\left[10^{-8} 1 / \mathrm{yr}\right]$ & $T_{s}[\mathrm{~km}]$ & $\dot{\varepsilon}_{x x}^{q}\left[10^{-8} 1 / \mathrm{yr}\right]$ & $\dot{\varepsilon}_{x x}^{q} / \dot{\varepsilon}_{x x}^{g}[\%]$ \\
\hline S. Pampeanas & $6 \pm 1$ & $400 \pm 50$ & $1.6 \pm 0.4$ & 40 & 1.50 & $70-130$ \\
C. Peru & $3 \pm 1$ & $350 \pm 50$ & $0.9 \pm 0.4$ & 45 & 0.50 & $40-100$ \\
N. Peru & $3 \pm 1$ & $350 \pm 50$ & $0.9 \pm 0.4$ & 40 & 0.85 & $65-170$ \\
Ecuador & $5 \pm 1$ & $300 \pm 50$ & $1.8 \pm 0.8$ & 30 & 2.70 & $170-270$ \\
\multicolumn{7}{c}{ Central Andean Plateau } \\
S. Bolivia & $7 \pm 1$ & $200 \pm 50$ & $3.5 \pm 1.2$ & 40 & 0.02 & $0.4-0.8$ \\
S. Peru & $4 \pm 1$ & $200 \pm 50$ & $2.0 \pm 1.2$ & 40 & 0.20 & $6-25$ \\
\hline
\end{tabular}

$v_{x}$ is the range-perpendicular shortening rate inferred from the GPS measurements of Kendrick et al. [2001], Nocquet et al. [2014] and Kendrick et al. [2006], and $W$ is the width of the deforming zone measured perpendicular to the range front based on earthquakes and geomorphology. $\dot{\varepsilon}_{x x}^{g}$ is the average horizontal strain rate perpendicular to the range, and is equivalent to $v_{x} / W . \dot{\varepsilon}_{x x}^{q}$ is the rangeperpendicular horizontal strain rate inferred from a summation of earthquake moment tensors using a shear modulus of $30 \mathrm{GPa}$ and the seismogenic thickness $T_{s}$. 
Table 2: Parameter range used to calculate the buoyancy force $F_{b}$ at different points along-strike.

\begin{tabular}{ccccccc}
\hline Region & $z_{l m}[\mathrm{~km}]$ & $z_{l f}[\mathrm{~km}]$ & $z_{c m}[\mathrm{~km}]$ & $z_{c f}[\mathrm{~km}]$ & $\Delta h[\mathrm{~km}]$ & $F_{b}[\mathrm{TN} / \mathrm{m}]$ \\
\hline Colombia & $150-175$ & $125-150$ & $60-65$ & $30-35$ & $2.7-3.0$ & $3.4 \pm 0.4$ \\
Ecuador & $100-150$ & $125-150$ & $50-60$ & $30-35$ & $2.8-3.0$ & $3.2 \pm 0.3$ \\
N. Peru & $100-150$ & $125-150$ & $50-55$ & $35-40$ & $2.8-3.2$ & $3.7 \pm 0.4$ \\
C. Peru & $100-150$ & $125-175$ & $65-75$ & $35-40$ & $3.8-4.2$ & $5.4 \pm 0.6$ \\
S. Peru & $150-175$ & $125-150$ & $70-75$ & $35-40$ & $4.0-4.3$ & $5.7 \pm 0.6$ \\
Bolivia & $150-200$ & $125-150$ & $70-75$ & $35-40$ & $3.5-3.8$ & $5.1 \pm 0.5$ \\
Puna & $150-175$ & $125-150$ & $70-75$ & $35-40$ & $4.0-4.5$ & $5.9 \pm 0.7$ \\
Pampeanas & $100-125$ & $100-125$ & $65-70$ & $35-40$ & $3.8-4.1$ & $5.2 \pm 0.4$ \\
\hline
\end{tabular}

$z_{l m}=$ lithosphere thickness beneath the mountains, $z_{l f}=$ lithosphere thickness beneath the forelands, $z_{c m}=$ crustal thickness beneath the mountains, $z_{c f}=$ crustal thickness beneath the forelands, and $\Delta h$ is the height difference between the mountain range and foreland. The mean of $F_{b}$ and the 95th percentile range of models are quoted. The fixed parameters are: crustal density $=2800 \mathrm{~kg} / \mathrm{m}^{3}$, mantle density $=3330 \mathrm{~kg} / \mathrm{m}^{3}$, density difference between depleted mantle lithosphere and asthenosphere $=$ $-50 \mathrm{~kg} / \mathrm{m}^{3}$, crustal thermal expansivity $=3 \times 10^{-5} \mathrm{~W} / \mathrm{m} / \mathrm{K}$, Moho temperature beneath the mountains $700-1000{ }^{\circ} \mathrm{C}$, and Moho temperature beneath the forelands $=600-700{ }^{\circ} \mathrm{C}$. 


\section{Figures}
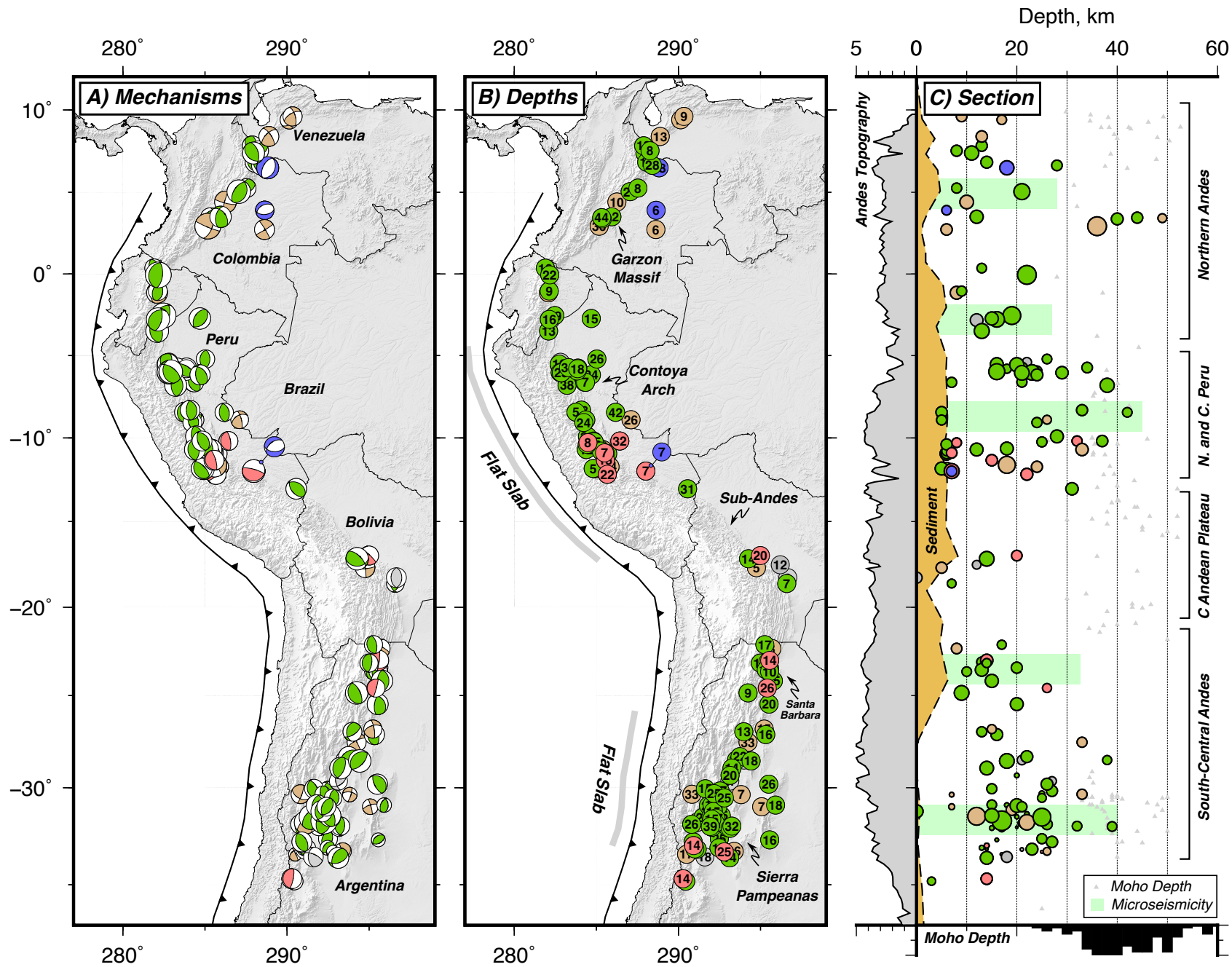

Figure 1: Well-constrained focal mechanisms and centroid depths for earthquakes in the forelands of the Andes. (a) Earthquake mechanisms coloured by the mechanism type, with reverse faults in green, low-angle thrusts in red, normal faults in blue and strike-slip faults in brown. (b) Earthquake centroid depths in kilometres. (c) Section of the centroid depth distribution in the forelands along-strike. Grey circles in (c) are events that do not have a well-constrained focal mechanism. Each circle is scaled in size by the earthquake magnitude. Green bars represent the depth extent of microseismicity from local earthquake and aftershock surveys. The Moho depth variation in the foreland is shown by grey triangles and is taken from receiver function studies [Assumpção et al., 2013; Poveda et al., 2015; Condori et al., 2017]. The sediment thickness in the foreland is taken from Golonka et al. [1995]. 


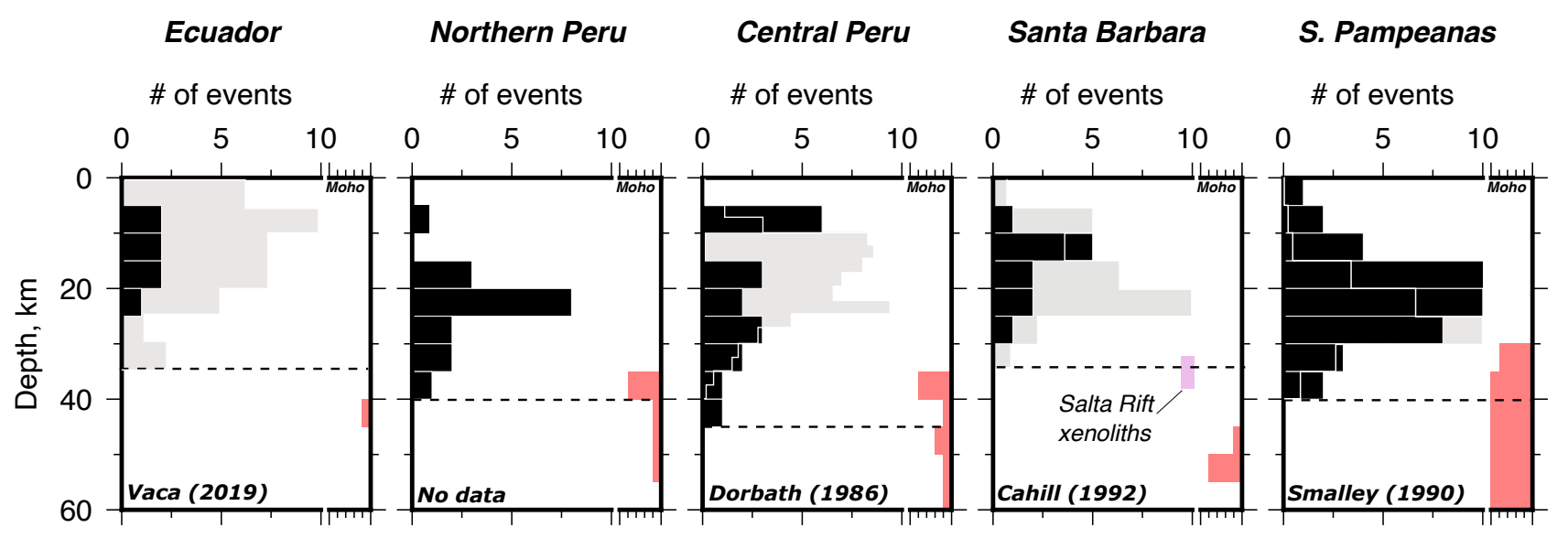

Figure 2: Histograms of the centroid depths of moderate-magnitude earthquakes (black bars), and regional and local microseismicity studies (grey bars with white outline), in different sections of the forelands. The maximum number of microseismic events in each region is normalised to 10 to display the relative distribution with depth. The source of the microseismicity data is shown in the bottom left of each plot. A histogram of the Moho depth in each region is also shown by the red bars on the right of each plot. The horizontal black-dashed line marks the thickness of the seismogenic layer $T_{s}$ to the nearest $5 \mathrm{~km}$. The depth range of granulite xenoliths erupted from the Salta Rift (discussed in Section 5) are shown by a purple bar. 

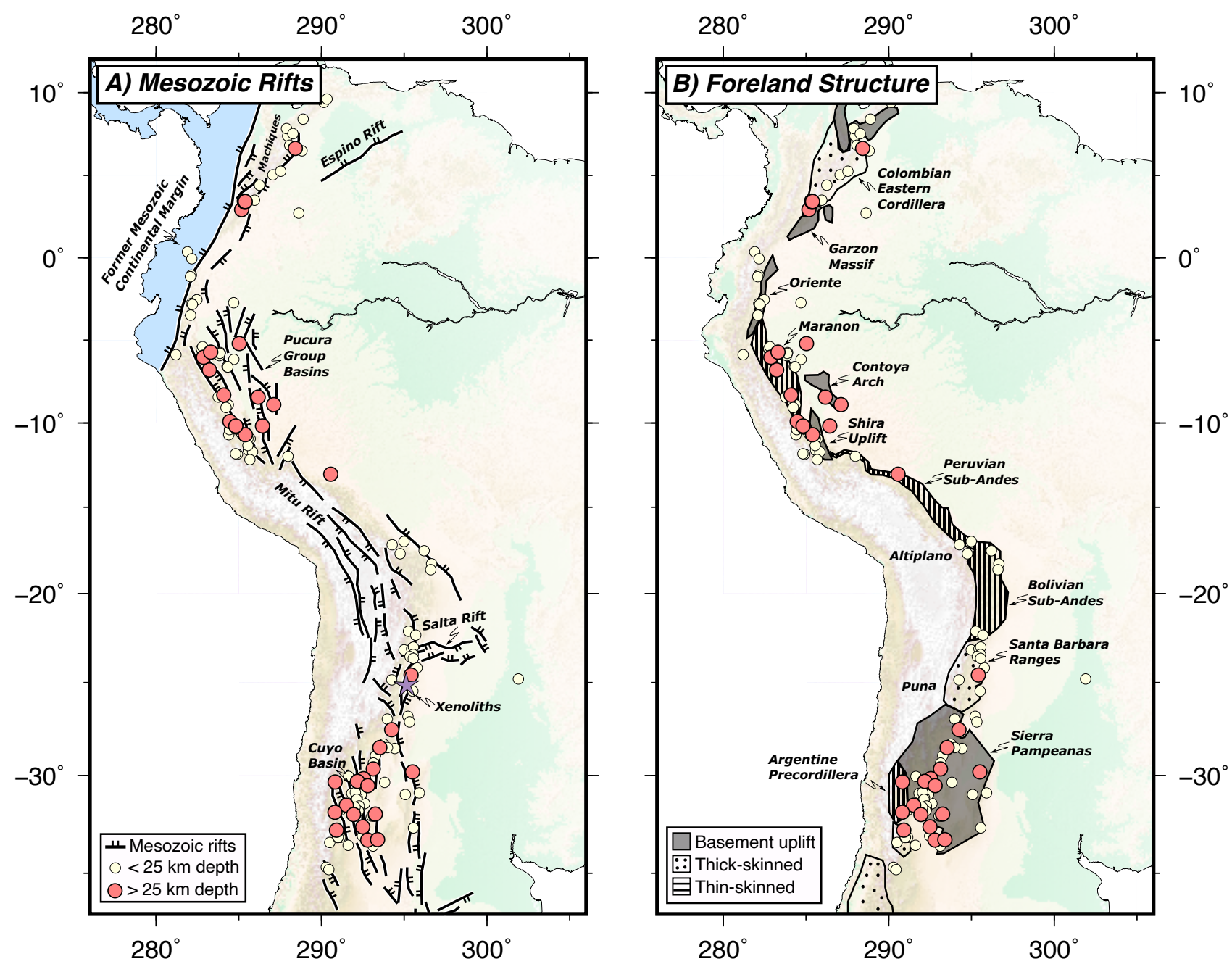

Figure 3: Earthquake distribution compared to the loci of Mesozoic rifts (a) and the structural style of deformation in the Andean forelands (b). The simplified traces of the Mesozoic rifts in (a) are taken from Ramos [2009] and McGroder et al. [2015]. Earthquakes are shown by circles and are coloured light red if they have a centroid depth $>25 \mathrm{~km}$. Rift-related faults running through the Chilean forearc and Andes are omitted to highlight regions where the rifts lie along the margins of the mountain range. The location of the xenolith suite of Lucassen et al. [1999] discussed in Section 5 is shown by a purple star. In (b) the along-strike variability in the structural style of foreland deformation is split into three different styles: thin-skinned, thick-skinned and basement uplifts. The deformation style is taken from Kley et al. [1999]. 
A)

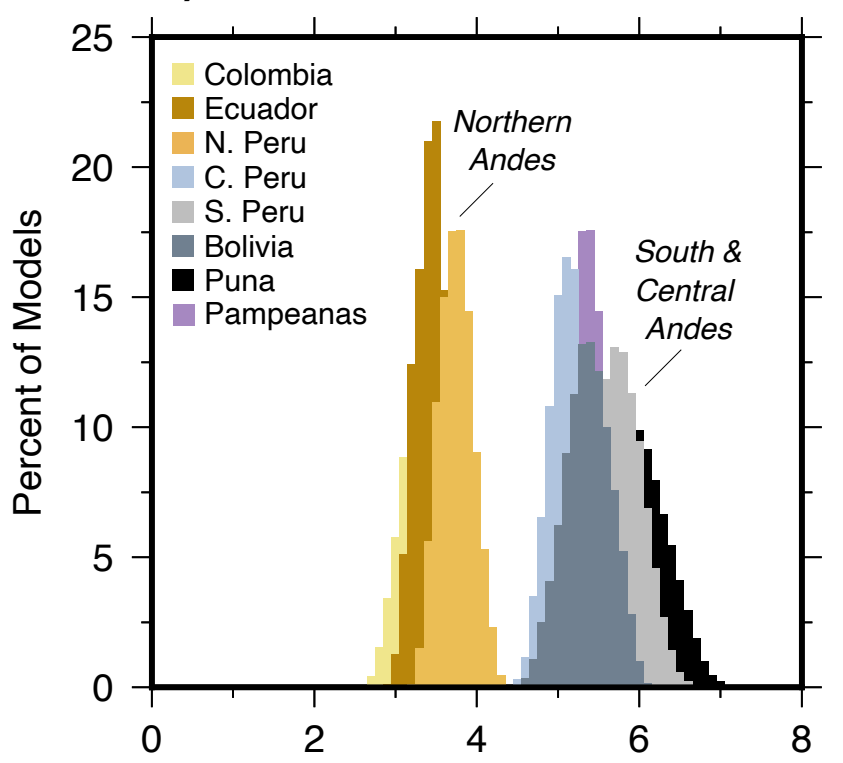

Buoyancy Force $\left(\times 10^{12}\right), \mathrm{N} / \mathrm{m}$
B)

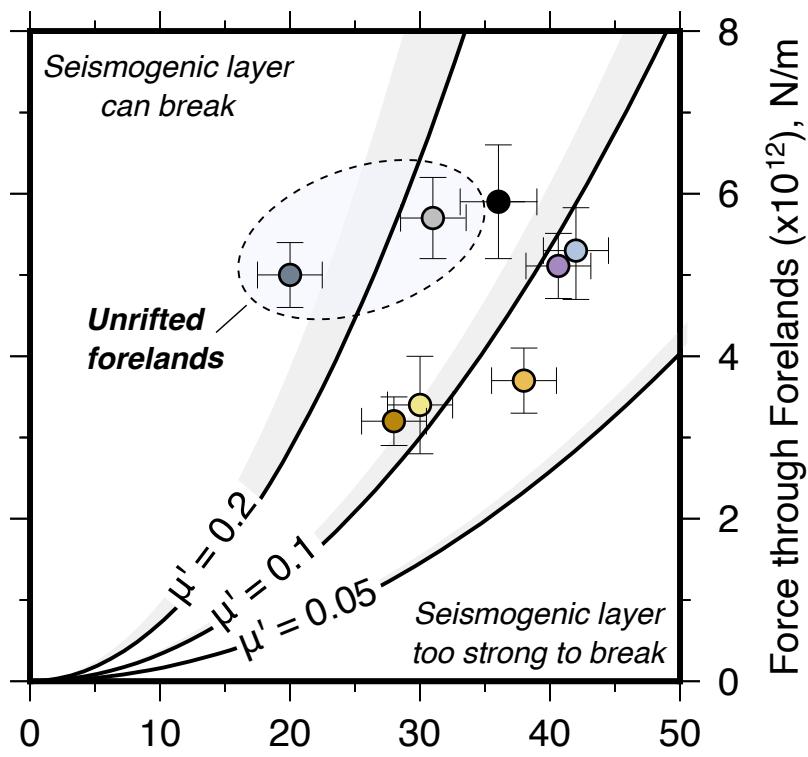

Seismogenic Thickness, $\mathrm{km}$

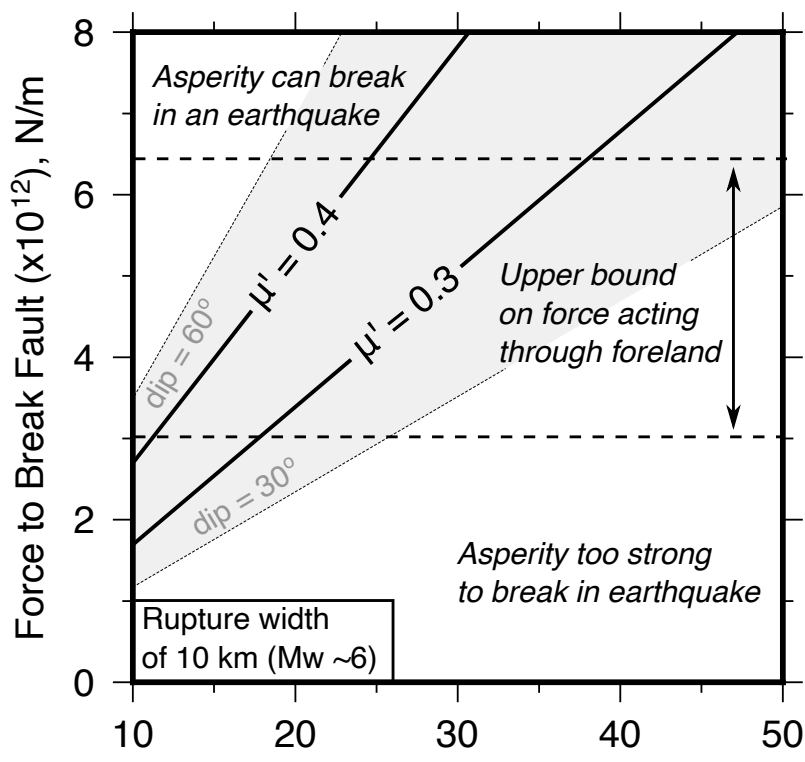

D)

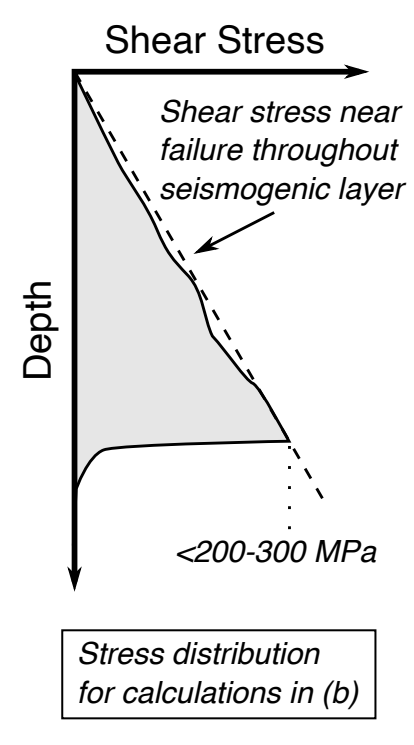

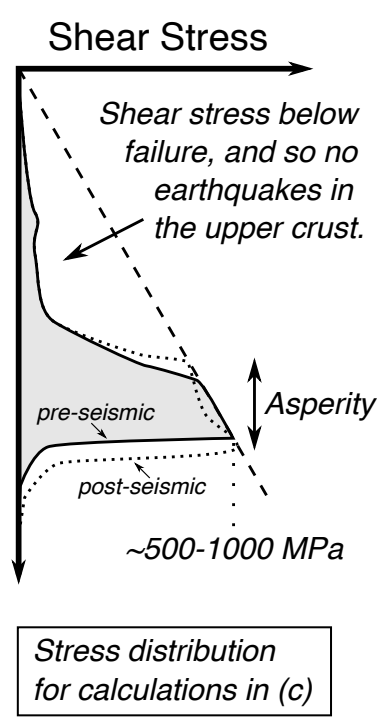

Earthquake Centroid Depth, km

Figure 4: Calculations of the forces acting through the foreland lithosphere and the frictional properties of the foreland faults. (a) Histogram of the buoyancy force $F_{b}$ acting between the mountains and forelands in seven different regions of the Andes (parameters in Table 2). (b) Seismogenic thickness $T_{s}$ against the estimate of the force acting through the foreland lithosphere $F_{f}$. The uncertainty bars are $\pm 3 \mathrm{~km}$ in $T_{s}$ and the 95 -th percentile of the models in $F_{f}$. The thick black lines show the force required to break the seismogenic layer $F_{s l}$ for a given $T_{s}$ along reverse faults with a $45^{\circ}$ dip. Grey-shaded regions show the range of $F_{s l}$ for fault dips between $30^{\circ}$ and $60^{\circ}$. (c) Calculation for the force required to break fault asperities in the forelands of the Andes in a $M_{w} \sim 6$ earthquake at a given centroid depth, assuming a dip of $45^{\circ}$ (thick black lines) or 30-60 (grey-shaded region). Horizontal-dashed lines show the force available to break the asperity from (a). (d) Schematic diagram showing the stress distribution with depth along an active fault assumed in the calculations shown in (b) and (c). 
A) P-T-t Evolution of the Salta Rift

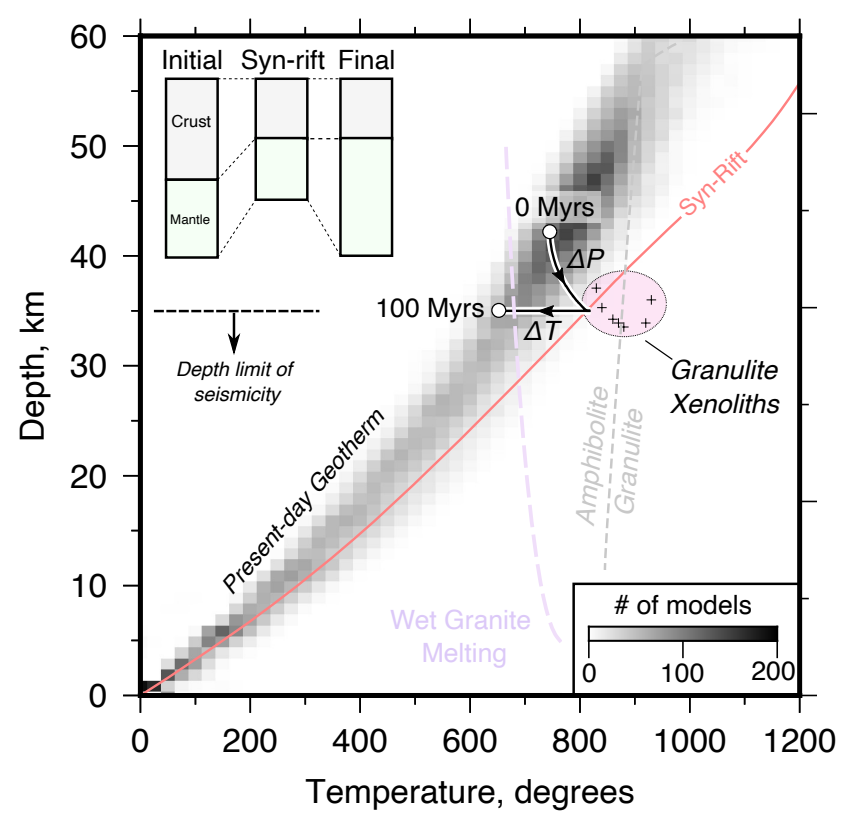

$\Delta T(35 \mathrm{~km})$, degrees $\quad \Delta P(35 \mathrm{~km}), \mathrm{GPa}$
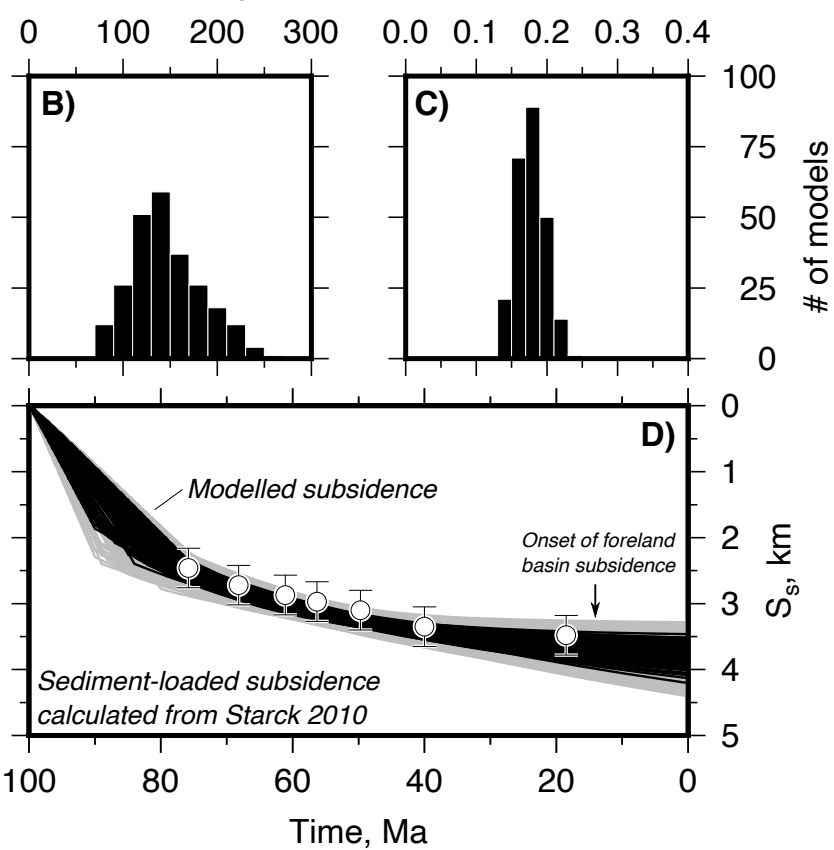

Figure 5: Theoretical estimates of the pressure-temperature-time $(P-T-t)$ evolution for rocks in the lower crust beneath the Salta Rift calculated using thermo-kinematic models that fit the sedimentloaded subsidence history within the Metán-Alemania Basin and the temperature constraints from xenolith thermobarometry. (a) Example $P-T$ - $t$ history for rocks exhumed to $35 \mathrm{~km}$ depth (black line) and the associated syn-rift geotherm (light red line) from one particular model. The range of possible present-day geotherms is shown by the density plot in the background, which is calculated from all of the models that match the geological constraints and the observed subsidence history $\left(S_{s}\right)$ to within $\chi^{2}<3$ (see Supplementary Text S2). (b) Distribution of the temperature decrease $\Delta T$ for a rock volume exhumed to $35 \mathrm{~km}$ depth, and (c) distribution of the equivalent pressure decrease $\Delta P$ assuming a crustal density of $2800 \mathrm{~kg} / \mathrm{m}^{3}$. (d) Decompacted sediment-loaded subsidence history $\left(S_{s}\right)$ in the Metán-Alemania Basin from Starck [2010] (white dots) and the model predictions $\left(S_{m}\right)$. Black lines $=$ models that fit to within $\chi^{2}<1$, grey lines $=$ models that fit to within $\chi^{2}<3$. 
Nothern and South-

\section{Central Andes}

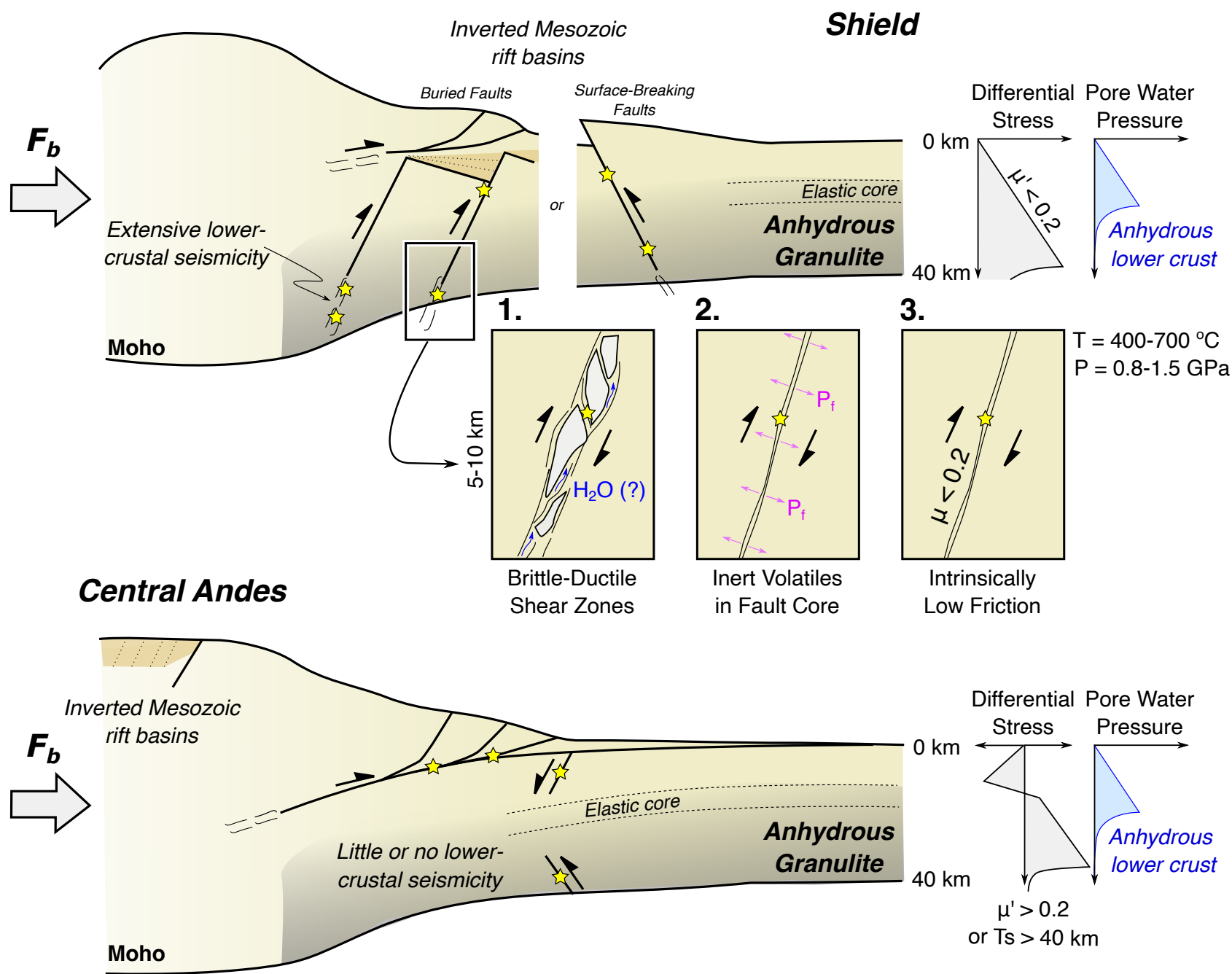

Figure 6: Sketches of the two contrasting styles of shortening in the forelands of the northern and south-central Andes (top) and the central Andes (bottom), adapted from Figure 7 in Watts et al. [1995]. In the northern and south-central Andes, frictionally-weak faults inherited from Mesozoic rift systems that cut through the lower crust are breaking in earthquakes down to $\sim 40-45 \mathrm{~km}$ depth. Three different mechanical explanations for how these deep faults may be both seismogenic and frictionally weak are shown, with each of these mechanisms being consistent with a dry lower crust beneath the Andean forelands. Along the margins of the central Andean plateau, there has been little or no recent seismicity in the lower crust, and the foreland is thought to underthrusting the high plateau. In this area the Mesozoic rift basins can be identified within the interior of the mountain range. The top of the foreland crust is in extension and its base is in compression, suggesting the seismogenic layer is bending beneath the mountains. 